\title{
Key pathways involved in prostate cancer based on gene set enrichment analysis and meta analysis
}

\author{
Q.Y. Ning ${ }^{1}$, J.Z. Wu ${ }^{1}$, N. Zang ${ }^{2}$, J. Liang ${ }^{3}$, Y.L. Hu ${ }^{2}$ and Z.N. Mo ${ }^{4}$ \\ ${ }^{1}$ Department of Infection, The First Affiliated Hospital of Guangxi Medical University, \\ Nanning, Guangxi Zhuang Autonomous Region, China \\ ${ }^{2}$ The Medical Scientific Research Centre, Guangxi Medical University, \\ Nanning, Guangxi Zhuang Autonomous Region, China \\ ${ }^{3}$ Department of Biology Technology, Guilin Medical University, \\ Guilin, Guangxi Zhuang Autonomous Region, China \\ ${ }^{4}$ Department of Urology, the First Affiliated Hospital of Guangxi Medical University, \\ Nanning, Guangxi Zhuang Autonomous Region, China \\ Corresponding authors: Y.L. Hu / Z.N. Mo \\ E-mail: ylhupost@163.com / mozengnan@gmail.com
}

Genet. Mol. Res. 10 (4): 3856-3887 (2011)

Received June 7, 2011

Accepted October 14, 2011

Published December 14, 2011

DOI http://dx.doi.org/10.4238/2011.December.14.10

\begin{abstract}
Prostate cancer is one of the most common male malignant neoplasms; however, its causes are not completely understood. A few recent studies have used gene expression profiling of prostate cancer to identify differentially expressed genes and possible relevant pathways. However, few studies have examined the genetic mechanics of prostate cancer at the pathway level to search for such pathways. We used gene set enrichment analysis and a meta-analysis of six independent studies after standardized microarray preprocessing, which increased concordance between these gene datasets. Based on gene set enrichment analysis, there were 12 down- and 25 up-regulated mixing pathways in more than two tissue datasets, while there were two down- and two up-regulated mixing pathways in three cell datasets. Based on the meta-analysis, there were 46 and nine common pathways in the tissue and cell datasets, respectively. Three up- and 10 down-regulated crossing pathways were
\end{abstract}


detected with combined gene set enrichment analysis and meta-analysis. We found that genes with small changes are difficult to detect by classic univariate statistics; they can more easily be identified by pathway analysis. After standardized microarray preprocessing, we applied gene set enrichment analysis and a meta-analysis to increase the concordance in identifying biological mechanisms involved in prostate cancer. The gene pathways that we identified could provide insight concerning the development of prostate cancer.

Key words: Prostate cancer; Gene set enrichment analysis; Meta-analysis

\section{INTRODUCTION}

Prostate cancer (PC) is one of the most common male malignant neoplasms in the world, and its incidence has increased year by year in China (Liang et al., 2007). Although large-scaled studies have been involved in prostate cancer, the mechanism involved still remained completely unclear until now. In order to reveal this mystery, a few recently reported studies have been developed using gene expression profiling of PC to identify differentially expressed genes from several to hundreds (Endo et al., 2009; Nadiminty et al., 2010), but these studies only focused on the individual gene. Prostate cancer is a complex disease and involves a number of gene interactions. Singling out and explaining individual genes on a list with a thousand important genes is still very difficult.

The major challenge for genome-wide RNA expression analysis is not to obtain gene expression profiles, but to extract a biological insight from the results (Subramanian et al., 2005). Of course, genome-wide expression analysis with DNA microarray have been used to identify predefined biological pathways associated with the phenotypic variations for many researches (Nanni et al., 2006; Chandran et al., 2007; Wallace et al., 2008). However, the confirmed biological pathways from these methods only represent a very small part of the entire range of pathways involved in prostate cancer.

To resolve this conflict, Mootha et al. (2003) described a method-Gene Set Enrichment Analysis (GSEA) which has been recognized as the most well-known and effective approach to gene set analysis. These authors have used it to identify predefined gene sets which showed significant differences in expression between normal and patient's samples. Subsequently, Subramanian et al. (2005) improved the methodology and specifically introduced the method of how to use GSEA.

GSEA which is based on the predefined sets of genes that usually derived from functional annotation or from results of prior experiments, can identify more subtle changes of gene expression, because the biggest advantage of GSEA is that the statistical results are obtained from groups or pathways rather than individual gene. Over the years, GSEA had been gradually applied to some areas (Suarez-Farinas et al., 2010 ). In addition, meta-analysis as a standard statistical method has become more widespread and has been applied in many fields. In this study, after a standardized microarray preprocessing for all the expression datasets, GSEA and a meta analysis were used to find the mixing pathways which provided a systematic insight into the pathways that changed during the mechanism of PC. 


\section{MATERIAL AND METHODS}

\section{Datasets}

The gene expression profiling studies about prostate cancer were searched from GEO (http://www.ncbi.nlm.nih.gov/geo/), and ArrayExpress (http://www.ebi.ac.uk/ arrayexpress/). Any data that met the following conditions was selected for inclusion: 1) the data was about genome-wide RNA expression; 2) the complete microarray raw or normalized data was effective; 3 ) the data provided a comparison between prostate cancer patients and controls; 4) Three or more samples were contained in the data.

Finally, we found five gene expression datasets which met the above criteria. In dataset GSE3868, two samples were removed because they were human prostate hyperplasia primary samples, and the other twenty-eight samples were all included in the processing. In dataset GSE6919 with U95 Version 2, 25 patients with metastatic prostate tumor samples in paratracheal lymph node and 63 patients with normal prostate tissue adjacent to the tumor were not included in the research. We summarized all the detailed information about the datasets, such as the first author or contributor, microarray platform, sample type, sample size, and they are shown in Table 1.

\begin{tabular}{|c|c|c|c|c|c|c|c|}
\hline \multirow[t]{2}{*}{ First author or contributor } & \multirow[t]{2}{*}{ Chip } & \multirow[t]{2}{*}{$\begin{array}{l}\text { GEO } \\
\text { accession }\end{array}$} & \multirow[t]{2}{*}{$\begin{array}{l}\text { Experimental } \\
\text { design }\end{array}$} & \multirow[t]{2}{*}{ Classification } & \multirow[t]{2}{*}{ Probs } & \multicolumn{2}{|c|}{$\begin{array}{l}\text { Number of } \\
\text { samples }\end{array}$} \\
\hline & & & & & & Disease & Normal \\
\hline $\begin{array}{l}\text { Yegnasubramanian S } \\
\text { (Yegnasubramanian et al., 2008) }\end{array}$ & U133 A & GSE12348 & unpaired, cells & prostate cancer & $22 \mathrm{~K}$ & 6 & 3 \\
\hline $\begin{array}{l}\text { Wallace TA } \\
\text { (Wallace et al., 2008) }\end{array}$ & U133A 2.0 & GSE6956 & unpaired, tissues & prostate cancer & $22 \mathrm{~K}$ & 69 & 20 \\
\hline Nanni S (Nanni et al., 2006) & U133A & GSE3868 & unpaired, cells & prostate cancer & $22 \mathrm{~K}$ & 23 & 5 \\
\hline $\begin{array}{l}\text { Chandran UR (Yu et al., 2004; } \\
\text { Chandran et al., 2007) }\end{array}$ & U95 Version 2 & GSE6919 & unpaired tissues & Prostate tumor & $12 \mathrm{~K}$ & 65 & 18 \\
\hline $\begin{array}{l}\text { Vellaichamy A } \\
\text { (Vellaichamy et al., 2009) }\end{array}$ & U133 Plus 2.0 & GSE17044 & unpaired, cells & prostate cancer cells & $54 \mathrm{~K}$ & 3 & 3 \\
\hline
\end{tabular}

Paried = compare prostate cancer to normal controls from the same patients with prostate cancer; Unparied = compare prostate cancer from men with prostate cancer to normal controls from men without prostate cancer; cells $=$ human prostate cancer cells samples.

\section{Data processing of standardized microarray preprocessing}

Software packages developed in version 2.10.1 of Bioconductor (Mootha et al., 2003) were applied for data preprocessing. The Robust Multichip Averaging (RMA) algorithm in the affy conductor package was used for each affymetrix raw dataset to calculate background adjusted, normalized and $\log 2$ probe-set intensities. The affy U133A normalizations shown in GSE3868 was also retained for further analysis. We selected genes which could be mapped to any explicit KEGG pathway for the further analysis of GSEA and meta-analysis. The measure of variability was within the interquartile range (IQR) and a cut-off was set up to remove IQR values under 0.5 for all the remaining genes. If one gene was targeted for multiple probe sets, we retained the probe set with the largest variability. Pathway analysis of each dataset was performed independently. 


\section{Data processing of GSEA}

GSEA performed using the Category version 2.10.1 package (Mootha et al., 2003). The gene sets represented by more than 10 genes were retained. The Student's-t-test statistical score was implemented in each pathway and the mean of the genes was calculated. A permutation test with 1000 times was used to identify the significantly changed pathways and p-value was less than or equaled to 0.05 .

\section{Data processing of meta-analysis}

To obtain the common gene sets for the datasets regarding prostate tissues or cells independently from the above remaining genes of each dataset, we then calculated the chisquare value of each gene based on the formula according to Brown (1975):

$$
\mathrm{X}^{2}=-2 \sum_{\mathrm{i}=1}^{\mathrm{K}} \log _{e} \mathrm{p}^{\mathrm{i}}
$$

and a cut-off was also set up to remove chi-square values under 0.05 for all the surplus genes which were used to obtain the pathways of the KEGG from DAVID Bioinformatics Resources 6.7 (http://david.abcc.ncifcrf.gov/). $K$ is the number of datasets.

\section{RESULTS}

\section{Re-analyzing each dataset to produce differentially expressed pathways}

The five inclusion datasets contain 166 prostate cancer cases and 49 controls. All the datasets were implemented with a common GSEA method. For each separate analysis, the significant pathways and the genes were also obtained with GSEA and the detailed information about the analysis results are shown in Table 2.

In our studies, experimental design of 2 datasets (Chandran et al., 2007; Wallace, 2008) was related to prostate cancer tissues, while the other three datasets (Nanni et al., 2006; Yegnasubramanian et al., 2008; Vellaichamy et al., 2009) were related to prostate cancer cells. Finally, we found that the consistent pathways were separate in tissue and cell from GSEA and the meta-analysis result.

\begin{tabular}{|c|c|c|c|c|c|c|}
\hline Studies & $\begin{array}{c}\text { Number of } \\
\text { patients }\end{array}$ & $\begin{array}{c}\text { Number of } \\
\text { controls }\end{array}$ & $\begin{array}{c}\text { Number of genes } \\
\text { after pre-processing }\end{array}$ & $\begin{array}{c}\text { Number of pathways } \\
\text { have genes }>10\end{array}$ & $\begin{array}{l}\text { Up-regulated } \\
\text { pathways }\end{array}$ & $\begin{array}{c}\text { Down-regulated } \\
\text { pathways } \\
\end{array}$ \\
\hline GSE17044 & 3 & 3 & 2421 & 219 & 0 & 0 \\
\hline GSE12348 & 6 & 3 & 2184 & 217 & 38 & 30 \\
\hline GSE3868 & 23 & 5 & 3814 & 216 & 6 & 17 \\
\hline GSE6956 & 69 & 20 & 2214 & 214 & 93 & 10 \\
\hline GSE6919 U95 Version 2 & 65 & 18 & 1810 & 213 & 72 & 1 \\
\hline
\end{tabular}




\section{Common significant pathways obtained from two prostate cancer tissue datasets by GSEA}

There were 1 up and 53 down-regulated pathways that existed in 2 prostate cancer tissues datasets, the details can be seen in Additional Table 1. The up-regulated pathway concerned genetic information processing and translation. Most of the representative pathways in down-regulated pathways were associated with metabolism, biosynthesis, signal transduction, cell communication and organismal systems.

\section{Common significant pathways obtained from three prostate cancer cell datasets by GSEA}

Except for prostate cancer tissues, datasets regarding prostate cancer cells were also added to our studies. For single datasets analysis, there was no up or down-regulated pathway detected in GSE17044. The reason may be that there was only a limited number of samples available. There were 38 up- and 30 down-regulatory pathways in GSE12348, and 6 and 17 in GSE3868. Also, there were four mixing pathways including 2 up and 2 down-regulated pathways from these 2 datasets. The details are shown in Additional Table 2.

\section{Common significant pathways obtained from these prostate cancer datasets by meta-analysis}

To further identify the results, we obtained common significant pathways and genes from these datasets by meta-analysis. In total, there were 1905 significant genes and 39 common pathways in two tissues datasets. Most of these pathways concernedCancers, Cardiovascular Diseases, Cell Communication, Signal Transduction, Cellular Processes, Environmental Information Processing, Human Diseases and Organismal Systems. The details are shown in Additional Table 3. Otherwise, 131 significant genes and 9 common pathways were identified in the three cell datasets. The main pathways concerned Lipid Metabolism and Amino Acid Metabolism. The results are shown in Additional Table 4.

\section{Common crossing significant pathways between the results of GSEA and meta-analysis}

To search the intersection pathways, a comparative analysis was made independently between the common significant pathways of GSEA and meta-analysis in cancer tissues or cells. Finally, 15 consistent pathways were obtained in tissue datasets and the details are shown in Additional Table 5. In this table, the pathways were primarily concerned metabolism, environmental information processing, signal transduction, signaling molecules and interaction, human diseases, cancers. However, no consistent pathways were detected in cell datasets.

\section{mRNA expression in human prostate cancers tissue}

In order to improve the above results, we searched for a dataset which was able to show the experience according to prostate carcinoma $v s$ normal tissue using the publically 
available ONCOMINE cancer gene expression microarray database (Singh et al., 2002). The platform for this dataset is U95Av2 arrays (Affymetrix). The sample included 50 normal and 52 tumor prostate tissues. The raw data was downloaded from (http://www.broadinstitute. org/cgi-bin/cancer/publications/pub_paper.cgi?mode=view\&paper_id=75). We also used the same GSEA program to enrich the pathways. Finally, we enriched 27 up-regulated and 66 down-regulated pathways. The results are shown in Additional Table 6. Except for two pathways, which is glycolysis/gluconeogenesis, starch and sucrose metabolism, the other 13 pathways as shown in Additional Table 5 were included in these enriched pathways.

\section{DISCUSSION}

PC is one of the most serious diseases and its mechanism still remains completely unclear. No single theory can provide a perfect definition for all the different cases of prostate cancer. The genome-wide microarrays can locate gene families and pathways which show a consistent alteration in a disease state. Pathway analysis is a valid method to reduce a major deviation and can obtain interesting common genes and pathways by mixing differently expressed genes from different datasets. Therefore, we can apply the pathway analysis to search for genes which are difficult to detect by univariate statistical analysis because of their subtle change. Gene set enrichment analysis and a meta-analysis were applied to five datasets to extract biological insights involved in prostate cancer. Our findings suggest that most of the pathways and genes that affect prostate cancer were accordant. In our study, according to functional classification, we discussed several differentially expressed pathways and genes among crossing pathways as shown in Additional Table 5 and which suggest the role of these pathways and genes in prostate cancer.

\section{Environmental information processing}

Environmental information processing includes membrane transport, signal transduction, signaling molecules and interaction etc. In our findings, signal transduction, signaling molecules and interaction are common functions in positive pathways. Signal transduction is related to cell proliferation, differentiation and apoptosis. Because most of the signaling molecules and interaction are involved in the processing of signal transduction, signaling molecules and interaction connect closely with signal transduction and may play an important role in the course of prostate cancer. Currently, numerous studies have been applied to explore signal transduction to understand the biological mechanism of prostate cancer (Skvortsova et al., 2008; Aalinkeel et al., 2010). The mitogen-activated protein kinase (MAPK) signaling pathway in our studies which belongs to signal transduction is related to various cellular functions. The MAPK cascade is a highly conserved module that is involved in various cellular functions, including cell proliferation, differentiation and migration (Takeda and Ichijo, 2002). A number of genes expression in this pathway have been reported to be related with prostate cancer i.e. CD14(+) cells exhibiting reduced expression of HLA-DR molecules in PCa patients. These cells suppress immune cell function in vitro and, therefore, immunotherapy protocols for PCa patients must be factored into the design (Vuk-Pavlovic et al., 2010). MYC oncogene overexpression induces prostatic intraepithelial neoplasia and loss of Nkx3.1 in mouse luminal epithelial cells (Iwata et al., 2010). Overexpression of NF-kappaB2/p52 
enhances androgen-sensitive LNCaP human prostate cancer cell growth and clonogenic ability in androgen-deprived condition in vitro. NF-kappaB2/p52 induced androgen-independent growth occurs via protecting LNCaP cells from apoptotic cell death and cell cycle arrest induced by androgen-deprivation. Adenoviral mediated NF-kappaB2/p52 expression in LNCaP cells enhances tumor growth in intact male nude mice and induces tumor growth in castrated male nude mice, suggesting that overexpression of NF-kappaB2/p52 induces androgen-independent growth of androgen-sensitive LNCaP cells (Nadiminty et al., 2008). CD44+ cells possess stem cell characteristics and highly expressed genes known to be important in stem cell maintenance. In addition, they have shown a strong tumorigenic potential in the clonogenic assay and soft agar colony formation assay (Lee et al., 2011).

\section{Cellular processes and cell communication}

Except for signal transduction and signaling molecules and interaction, cellular processes and cell communication are also a way of obtaining information transmission between cells. Many junctions among cells are the structural characteristics of smooth muscle and become a channel connected cytoplasm in order to transmit cellular information. Numerous recent studies suggest that the disruption of cell-cell adhesion may be a key mechanism associated with calcitonin (CT)-stimulated prostate cancer progression and metastasis (Shah et al., 2008). Gap junction has been considered to be an important part of junctional communication in the prostate morphogenesis and oncogenesis (Mitra et al., 2006) and may also play a pivotal role in invasion and migration of prostate cancer cells (Tate et al., 2006). The idea that focal adhesion is related to cell movement suggests focal adhesion which may be involved in the development and metastasis of tumors. Recent studies have tested the hypothesis (Franzen et al., 2009). Epithelial tight junctions are composed of at least three types of transmembrane protein. The transmembrane proteins mediate cell adhesion and are thought to constitute the intramembrane and paracellular diffusion barriers (Balda and Matter, 2003). Cell growth, reproduction, differentiation and apoptosis are involved in signal transduction of cell transmembrane. Therefore, the factors which affect signal transduction of cell transmembrane will possibly interrupt the function of normal cells. The actin cytoskeleton participates in many fundamental processes including the regulation of cell shape, motility, and adhesion. The remodeling of the actin cytoskeleton is dependent on actin binding proteins, which organize actin filaments into specific structures that allow them to perform various specialized functions (Revenu et al., 2004). Therefore, cell communication may be a possible significant factor for an insight into the biological mechanism of prostate cancer.

\section{Metabolism pathways}

The metabolism pathways in our study were mainly focused on lipid metabolism, amino acid metabolism and xenobiotics biodegradation and metabolism. It has been recently confirmed that genes and proteins involved in cellular metabolism play a crucial part in the development and progression of PC (Pettazzoni et al., 2011; Ouyang et al., 2011). Glycolysis/Gluconeogenesis pathway belongs to the lipid metabolism. Glycolysis is the process of converting glucose into pyruvate and generating small amounts of adenosine-5'-triphosphate (energy) and nicotinamide adenine dinucleotide. It can produce important precursor metabo- 
lites. The gene PGK1 in this pathway has been reported to be significantly differentially expressed between laser microdissected malignant versus benign clinical samples of prostate tissue (Romanuik et al., 2009). Uridine diphosphate (UDP)-glucose dehydrogenase (UGDH) in the amino acid metabolism pathway was found to be significantly differentially expressed in our analysis, and can also catalyze the oxidation of UDP-glucose to yield UDP-glucuronic acid which is a precursor for synthesis of glycosaminoglycans and proteoglycans that promote aggressive PC progression (Huang et al., 2010). Drug metabolism - cytochromes P450 was also observed in our search for pathways. The cytochromes P450 (CYPs) are key enzymes in cancer formation and cancer treatment. They mediate the metabolic activation of numerous precarcinogens and participate in the inactivation and activation of anticancer drugs. Therefore, this pathway may have a relationship with the mechanism of resistance to chemotherapy drugs in prostate cancer. In the finding genes of this pathway, CYP $3 A 4$ and CYP $3 A 5$ expression is related to androgen metabolism (Rebbeck et al., 2008). Meta-analysis studies show that measurement of GSTP1 promoter methylation in plasma, serum, or urine samples may complement PSA screening for prostate cancer diagnosis (Wu et al., 2011).

\section{Endocrine system}

The insulin signaling pathway in our study belongs to both the organismal and endocrine systems. Most of the positive genes in this pathway have been reported to be related to prostate cancer. Insulin binding to its receptor results in the tyrosine phosphorylation of insulin receptor substrates (IRS) by the insulin receptor tyrosine kinase. Signal transduction proteins interact with IRS including GRB2. GRB2 is part of the cascade including SOS, RAS, RAF, and MEK that lead to activation of MAPK and mitogenic response in the form of gene transcription. FASN can act as a prostate cancer oncogene in the presence of AR and then FASN exerts its oncogenic effect by inhibiting the intrinsic pathway of apoptosis (Migita e $\mathrm{t}$ al., 2009). Expression of p66(Shc) protein correlates with proliferation of human prostate cancer cells (Veeramani et al., 2005). Increasing mTOR activity and protein synthesis did not translate into enhanced cell proliferation rates. However, the lack of TSC2 resulted in a survival advantage when cells were exposed to hypoxia. Protection against hypoxia-induced cell death due to TSC2 deficiency is rapamycin-resistant, suggesting that TSC2 affects an apoptotic pathway. Tumors derived from TSC2 wild-type cells exhibited a growth delay compared with TSC2-deficient tumors, indicating that enhancing mTOR activity is advantageous in the initial phase of tumor growth (Kaper et al., 2006).

\section{Other pathways and genes}

As shown in Additional Table 3, except for the above pathways, the remaining pathways all belong to the classification of human diseases and cancers. Most of genes in these pathways can be enriched in the above pathways. Smad3 in chronic myeloid leukemia pathway is an important gene for prostate cancer and this has widely been reported in the literature. Smad3 has been shown to be the essential mediator of most Smad-dependent TGF-beta responses, including control of gene expression, cell growth, apoptosis, and tumor suppression (Yang et al., 2009). Deregulated/enhanced expression and activation of AR in prostate carcinomas may intercept the tumor suppressor function of TGF- $\beta$ through transcriptional suppres- 
sion of Smad3 (Song et al., 2010).

\section{CONCLUSION}

The pathogenesis of $\mathrm{PC}$ is quite complicated. We were able to gain an insight into the mechanisms by focusing on gene sets or pathways rather than on individual genes. In our research, many consistent biological mechanisms involved in PC were identified by GSEA and meta-analysis after a standardized microarray preprocessing, which were original in terms of their connection to PC (as obtained from the current literature). In addition, the enriched pathways can be improved by a tissue dataset from the Oncomine database. Further studies about the specific role and interactions of the genes included in related pathways are needed to improve the understanding of prostate cancer.

\section{ACKNOWLEDGMENTS}

In this research, we had a great amount of help. During writing and running the program, Zhao Hongbo, Zhang Jiange, etc., provided substantial assistance. Research supported by the National Natural Science Foundation of China (grant \#81060213), Guangxi Natural Science Foundation (Grant \#2011GXNSFB018100).

\section{REFERENCES}

Aalinkeel R, Hu Z, Nair BB, Sykes DE, et al. (2010). Genomic Analysis Highlights the Role of the JAK-STAT Signaling in the Anti-proliferative Effects of Dietary Flavonoid-“Ashwagandha” in Prostate Cancer Cells. Evid. Based Complement. Alternat. Med. 7: 177-187.

Balda MS and Matter K (2003). Epithelial cell adhesion and the regulation of gene expression. Trends Cell Biol. 13: 310-318. Brown BM (1975). A Method for combining non-independent, one-sided tests of significance. Biometrics 31: 987-992.

Chandran UR, Ma C, Dhir R, Bisceglia M, et al. (2007). Gene expression profiles of prostate cancer reveal involvement of multiple molecular pathways in the metastatic process. BMC Cancer 7: 64 .

Endo T, Uzawa K, Suzuki H, Tanzawa H, et al. (2009). Characteristic gene expression profiles of benign prostatic hypertrophy and prostate cancer. Int. J. Oncol. 35: 499-509.

Franzen CA, Amargo E, Todorovic V, Desai BV, et al. (2009). The chemopreventive bioflavonoid apigenin inhibits prostate cancer cell motility through the focal adhesion kinase/Src signaling mechanism. Cancer Prev. Res. 2: 830-841.

Huang D, Casale GP, Tian J, Lele SM, et al. (2010). Udp-glucose dehydrogenase as a novel field-specific candidate biomarker of prostate cancer. Int. J. Cancer 126: 315-327.

Iwata T, Schultz D, Hicks J, Hubbard GK, et al. (2010). MYC overexpression induces prostatic intraepithelial neoplasia and loss of Nkx3.1 in mouse luminal epithelial cells. PLoS One 5: e9427.

Kaper F, Dornhoefer N and Giaccia AJ (2006). Mutations in the PI3K/PTEN/TSC2 pathway contribute to mammalian target of rapamycin activity and increased translation under hypoxic conditions. Cancer Res. 66: 1561-1569.

Lee EK, Cho H and Kim CW (2011). Proteomic analysis of cancer stem cells in human prostate cancer cells. Biochem. Biophys. Res. Commun. 412: 279-285.

Liang CH, Liu Q, Zhou FJ, Gao X, et al. (2007). Etiologic correlations of prostate cancer in Guangdong, China to family history of cancers, and sexual and marital factors-a case-control study. Ai Zheng 26: 484-488.

Migita T, Ruiz S, Fornari A, Fiorentino M, et al. (2009). Fatty acid synthase: a metabolic enzyme and candidate oncogene in prostate cancer. J. Natl. Cancer Inst. 101: 519-532.

Mitra S, Annamalai L, Chakraborty S, Johnson K, et al. (2006). Androgen-regulated formation and degradation of gap junctions in androgen-responsive human prostate cancer cells. Mol. Biol. Cell 17: 5400-5416.

Mootha VK, Lindgren CM, Eriksson KF, Subramanian A, et al. (2003). PGC-1alpha-responsive genes involved in oxidative phosphorylation are coordinately downregulated in human diabetes. Nat. Genet. 34: 267-273.

Nadiminty N, Chun JY, Lou W, Lin X, et al. (2008). NF-kappaB2/p52 enhances androgen-independent growth of human 
LNCaP cells via protection from apoptotic cell death and cell cycle arrest induced by androgen-deprivation. Prostate 68: $1725-1733$.

Nadiminty N, Dutt S, Tepper C and Gao AC (2010). Microarray analysis reveals potential target genes of NF-kappaB2/ p52 in LNCaP prostate cancer cells. Prostate 70: 276-287.

Nanni S, Priolo C, Grasselli A, D'Eletto M, et al. (2006). Epithelial-restricted gene profile of primary cultures from human prostate tumors: a molecular approach to predict clinical behavior of prostate cancer. Mol. Cancer Res. 4: 79-92.

Ouyang DY, Ji YH, Saltis M, Xu LH, et al. (2011). Valproic acid synergistically enhances the cytotoxicity of gossypol in DU145 prostate cancer cells: an iTRTAQ-based quantitative proteomic analysis. J. Proteomics 74: 2180-2193.

Pettazzoni P, Ciamporcero E, Medana C, Pizzimenti S, et al. (2011). Nuclear factor erythroid 2-related factor-2 activity controls 4-hydroxynonenal metabolism and activity in prostate cancer cells. Free Radic. Biol. Med. 51: 1610-1618.

Rebbeck TR, Rennert H, Walker AH, Panossian S, et al. (2008). Joint effects of inflammation and androgen metabolism on prostate cancer severity. Int. J. Cancer 123: 1385-1389.

Revenu C, Athman R, Robine S and Louvard D (2004). The co-workers of actin filaments: from cell structures to signals. Nat. Rev. Mol. Cell Biol. 5: 635-646.

Romanuik TL, Ueda T, Le N, Haile S, et al. (2009). Novel biomarkers for prostate cancer including noncoding transcripts. Am. J. Pathol. 175: 2264-2276.

Shah GV, Thomas S, Muralidharan A, Liu Y, et al. (2008). Calcitonin promotes in vivo metastasis of prostate cancer cells by altering cell signaling, adhesion, and inflammatory pathways. Endocr. Relat. Cancer 15: 953-964.

Singh D, Febbo PG, Ross K, Jackson DG, et al. (2002). Gene expression correlates of clinical prostate cancer behavior. Cancer Cell 1: 203-209.

Skvortsova I, Skvortsov S, Stasyk T, Raju U, et al. (2008). Intracellular signaling pathways regulating radioresistance of human prostate carcinoma cells. Proteomics 8: 4521-4533.

Song K, Wang H, Krebs TL, Wang B, et al. (2010). DHT selectively reverses Smad3-mediated/TGF-beta-induced responses through transcriptional down-regulation of Smad3 in prostate epithelial cells. Mol. Endocrinol. 24: 2019-2029.

Suarez-Farinas M, Lowes MA, Zaba LC and Krueger JG (2010). Evaluation of the psoriasis transcriptome across different studies by gene set enrichment analysis (GSEA). PLoS One 5: e10247.

Subramanian A, Tamayo P, Mootha VK, Mukherjee S, et al. (2005). Gene set enrichment analysis: a knowledge-based approach for interpreting genome-wide expression profiles. Proc. Natl. Acad. Sci. U. S. A. 102: 15545-15550.

Takeda K and Ichijo H (2002). Neuronal p38 MAPK signalling: an emerging regulator of cell fate and function in the nervous system. Genes Cells 7: 1099-1111.

Tate AW, Lung T, Radhakrishnan A, Lim SD, et al. (2006). Changes in gap junctional connexin isoforms during prostate cancer progression. Prostate 66: 19-31.

Veeramani S, Igawa T, Yuan TC, Lin FF, et al. (2005). Expression of p66(Shc) protein correlates with proliferation of human prostate cancer cells. Oncogene 24: 7203-7212.

Vellaichamy A, Sreekumar A, Strahler JR, Rajendiran T, et al. (2009). Proteomic interrogation of androgen action in prostate cancer cells reveals roles of aminoacyl tRNA synthetases. PLoS One 4: e7075.

Vuk-Pavlovic S, Bulur PA, Lin Y, Qin R, et al. (2010). Immunosuppressive CD14+HLA-DRlow/- monocytes in prostate cancer. Prostate 70: 443-455.

Wallace TA, Prueitt RL, Yi M, Howe TM, et al. (2008). Tumor immunobiological differences in prostate cancer between African-American and European-American men. Cancer Res. 68: 927-936.

Wu T, Giovannucci E, Welge J, Mallick P, et al. (2011). Measurement of GSTP1 promoter methylation in body fluids may complement PSA screening: a meta-analysis. Br. J. Cancer 105: 65-73.

Yang J, Wahdan-Alaswad R and Danielpour D (2009). Critical role of Smad2 in tumor suppression and transforming growth factor-beta-induced apoptosis of prostate epithelial cells. Cancer Res. 69: 2185-2190.

Yegnasubramanian S, Haffner MC, Zhang Y, Gurel B, et al. (2008). DNA hypomethylation arises later in prostate cancer progression than $\mathrm{CpG}$ island hypermethylation and contributes to metastatic tumor heterogeneity. Cancer Res. 68: 8954-8967. 


\section{SUPPLEMENTARY MATERIAL}

\begin{tabular}{|c|c|c|c|c|c|}
\hline Pathway & Pathway names & Classification & $P$ value & $\begin{array}{l}\text { Number of genes } \\
\text { expressed in the } \\
\text { pathways }\end{array}$ & Included genes \\
\hline 03010 & Ribosome & $\begin{array}{l}\text { Genetic information } \\
\text { processing and } \\
\text { translation }\end{array}$ & 0.01 & 36 & $\begin{array}{l}\text { RPL23P6, RPL27A, RPL29P11, RPL29P12, } \\
\text { RPL29P26, RPL29P9, RPL31P17, RPL31P49, } \\
\text { RPL38, RPL5P1, RPL5P34, RPS11P5, RPS19P3, } \\
\text { RPS28, RPS28P6, RPS28P9, RPS2P11, RPS2P12, } \\
\text { RPS2P17, RPS2P20, RPS2P5, RPS2P51, RPS2P55, } \\
\text { RPS2P8, RPI27, RP114, RP123, RPI28, RP129, RP131, } \\
\text { RP15, RPS11, RPS 19, RPS 2, RPS 20, RPS } 21\end{array}$ \\
\hline
\end{tabular}

Additional Table 2. Common significant pathways obtained from 3 prostate cancer cell datasets by GSEA up-regulated pathways.

\begin{tabular}{|c|c|c|c|c|c|}
\hline $\begin{array}{l}\text { Pathway } \\
\text { entry }\end{array}$ & Pathway names & Classification & $P$ value & $\begin{array}{l}\text { Number of genes } \\
\text { expressed in the } \\
\text { pathways }\end{array}$ & Included genes \\
\hline 00260 & $\begin{array}{l}\text { Glycine, serine and } \\
\text { threonine metabolism }\end{array}$ & $\begin{array}{l}\text { Amino acid } \\
\text { metabolism }\end{array}$ & 0.008 & 11 & $\begin{array}{l}\text { C8orf62; Gamt; MAOA; PHGDH; PSAT1; } \\
\text { PSPH; PSPHL; SHMT2; dld; gcat; srr }\end{array}$ \\
\hline 04120 & $\begin{array}{l}\text { Ubiquitin mediated } \\
\text { proteolysis }\end{array}$ & $\begin{array}{l}\text { sorting and } \\
\text { degradation }\end{array}$ & 0.008 & 65 & $\begin{array}{l}\text { ANAPC5; CUL5; CUL7; Fbxo2; Fbxw11; } \\
\text { HERC2; HUWE1; ITCH; KLHL9; } \\
\text { LOC100132973; LOC730429; NEDD4; } \\
\text { PIAS1; PIAS2; RBX1; SAE1; SMURF1; } \\
\text { SMURF2; STUB1; TCEB1; Tceb2; Trip12; } \\
\text { UBA2; UBA6; UBE2A; UBE2C; UBE2D3P; } \\
\text { UBE2E1; UBE2G2; UBE2I; UBE2J1; } \\
\text { UBE2MP1; UBE2N; UBE3B; UBE3C; } \\
\text { UBR5; Uba1; Uba7; Ube2e3; Ube2h; } \\
\text { Ube216; Ube2m; Ube2q1; Ube2s; Ube3a; } \\
\text { Ube4b; WWP1; WWP2; btrc; cul3; cul4a; } \\
\text { erc4; keap1; grn1; prpf19; rnf7; trim32; } \\
\text { uba3; ube2b; ube2d2; ube2d3; ube2d4; } \\
\text { ube2g1; ube213; ube4a }\end{array}$ \\
\hline
\end{tabular}


Q.Y. Ning et al.

3866

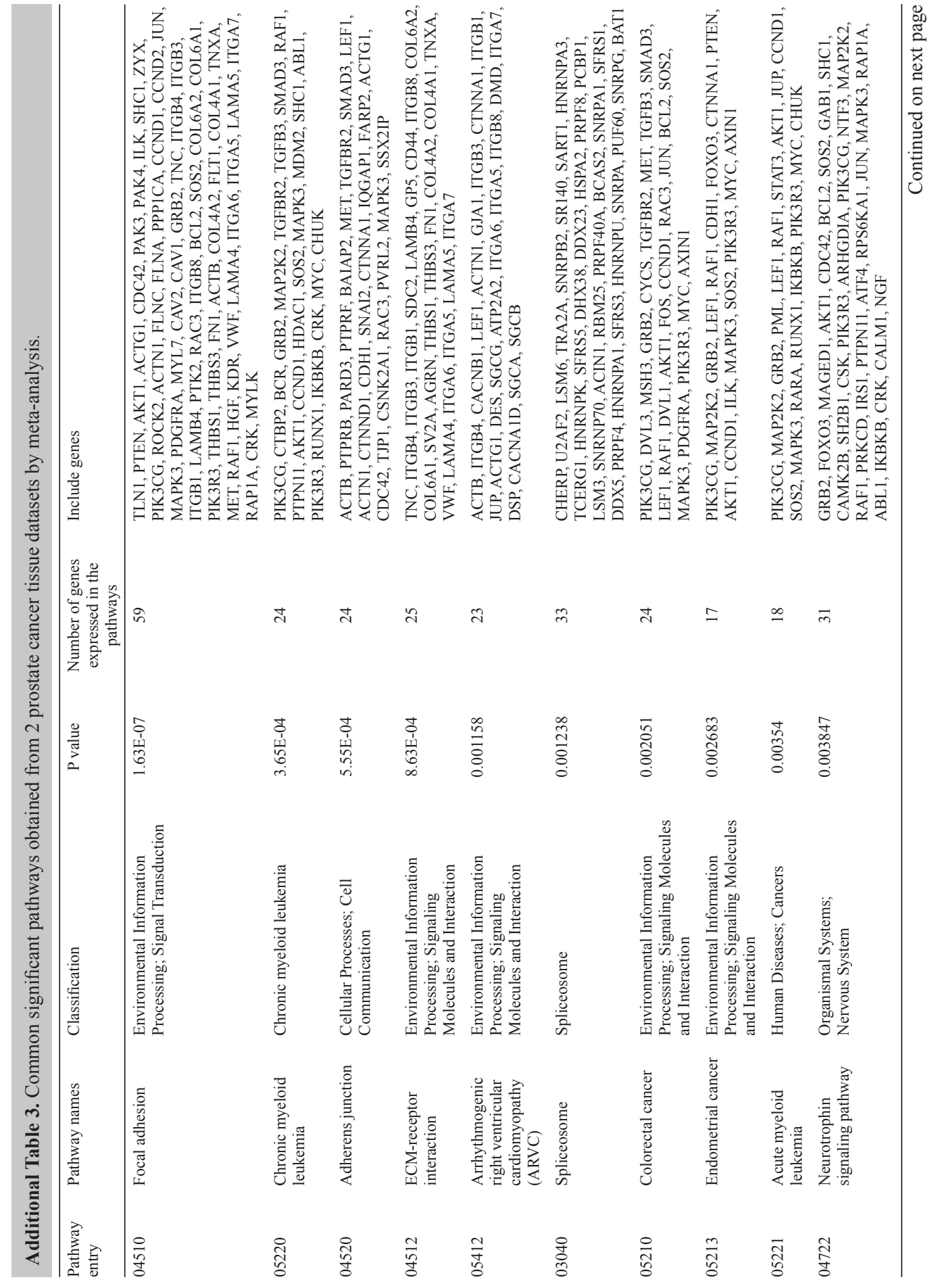

Genetics and Molecular Research 10 (4): 3856-3887 (2011)

CFUNPEC-RP www.funpecrp.com.br 
Key pathways involved in prostate cancer

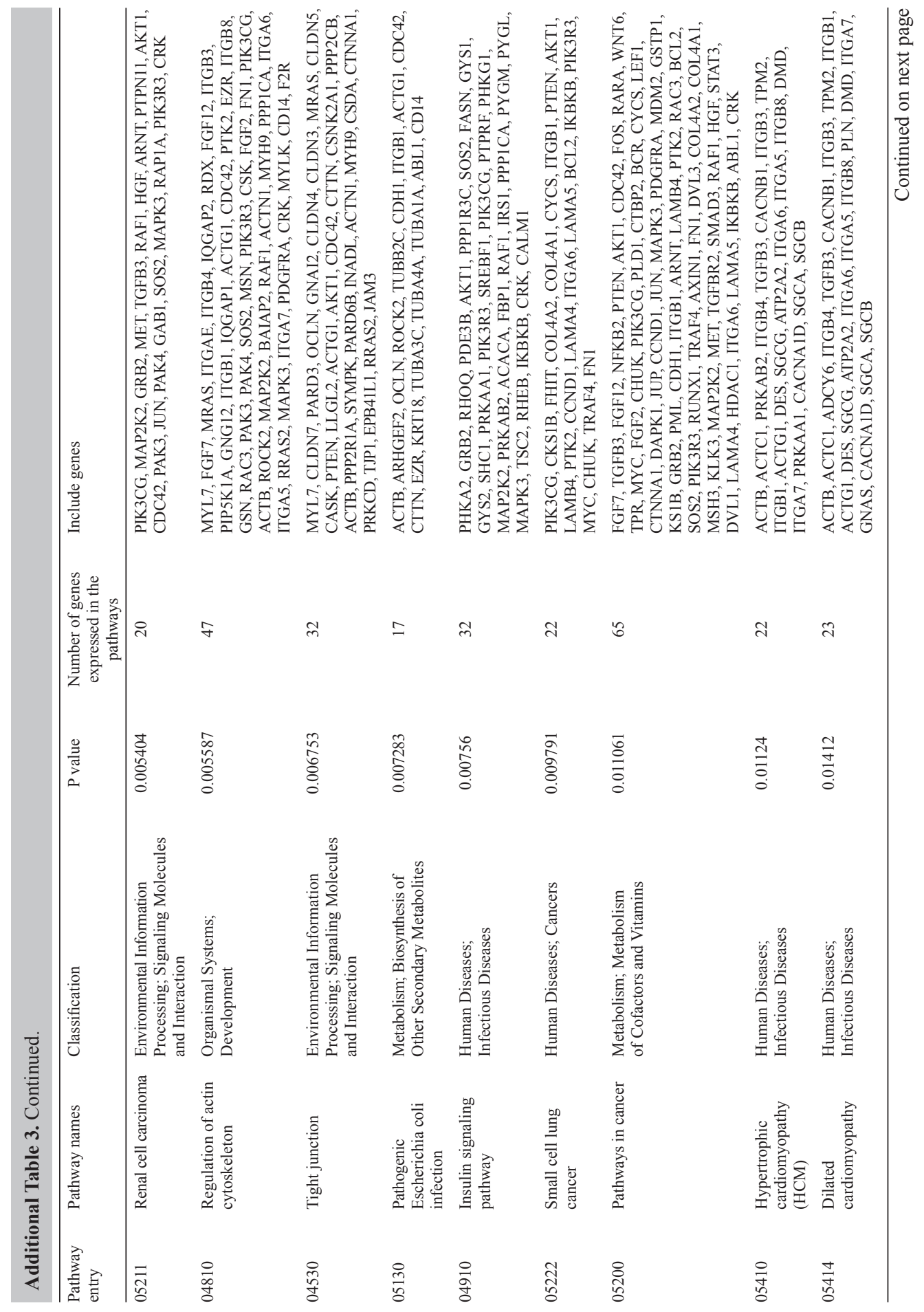

Genetics and Molecular Research 10 (4): 3856-3887 (2011) 
Q.Y. Ning et al.

3868

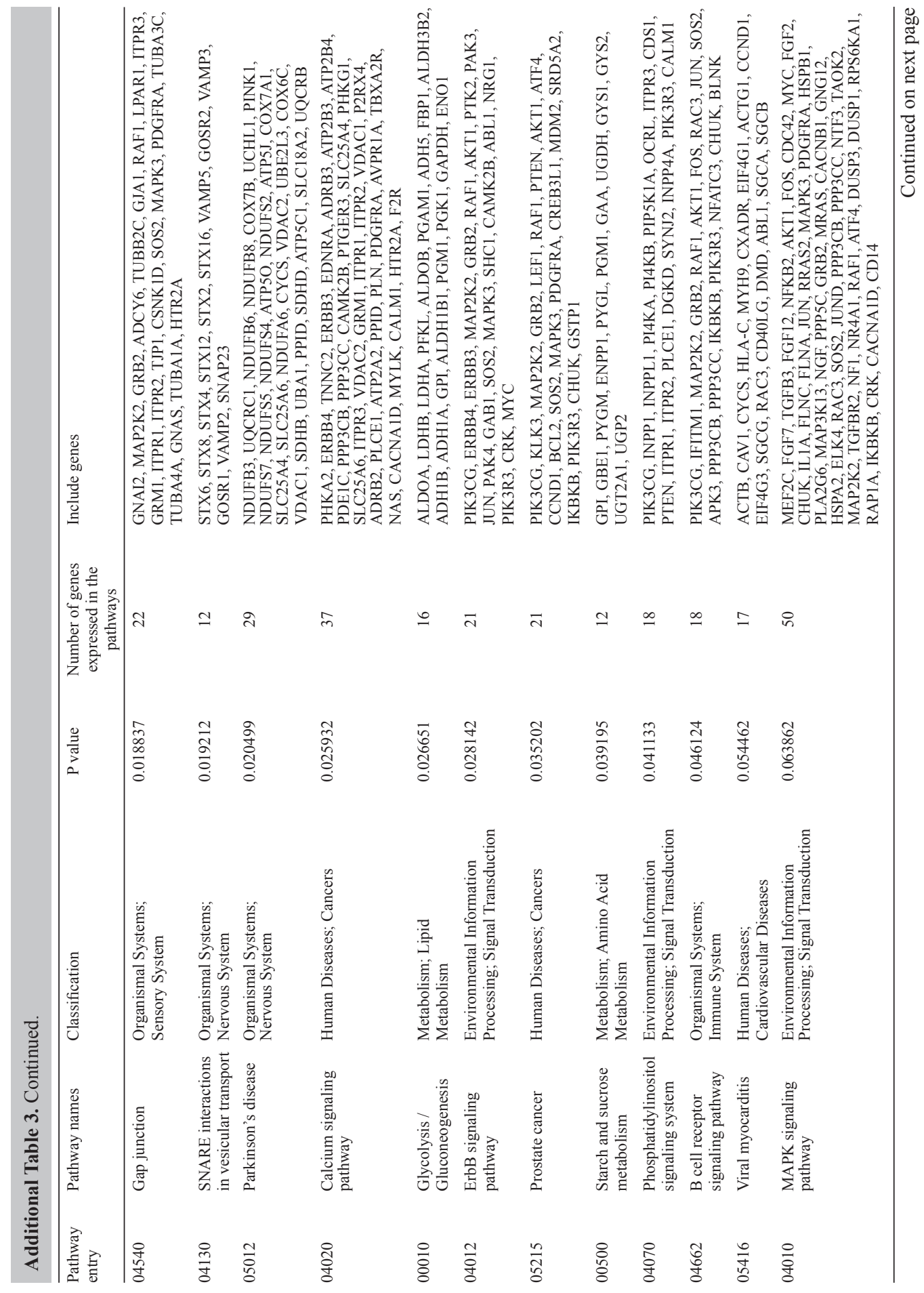

Genetics and Molecular Research 10 (4): 3856-3887 (2011)

CFUNPEC-RP www.funpecrp.com.br 


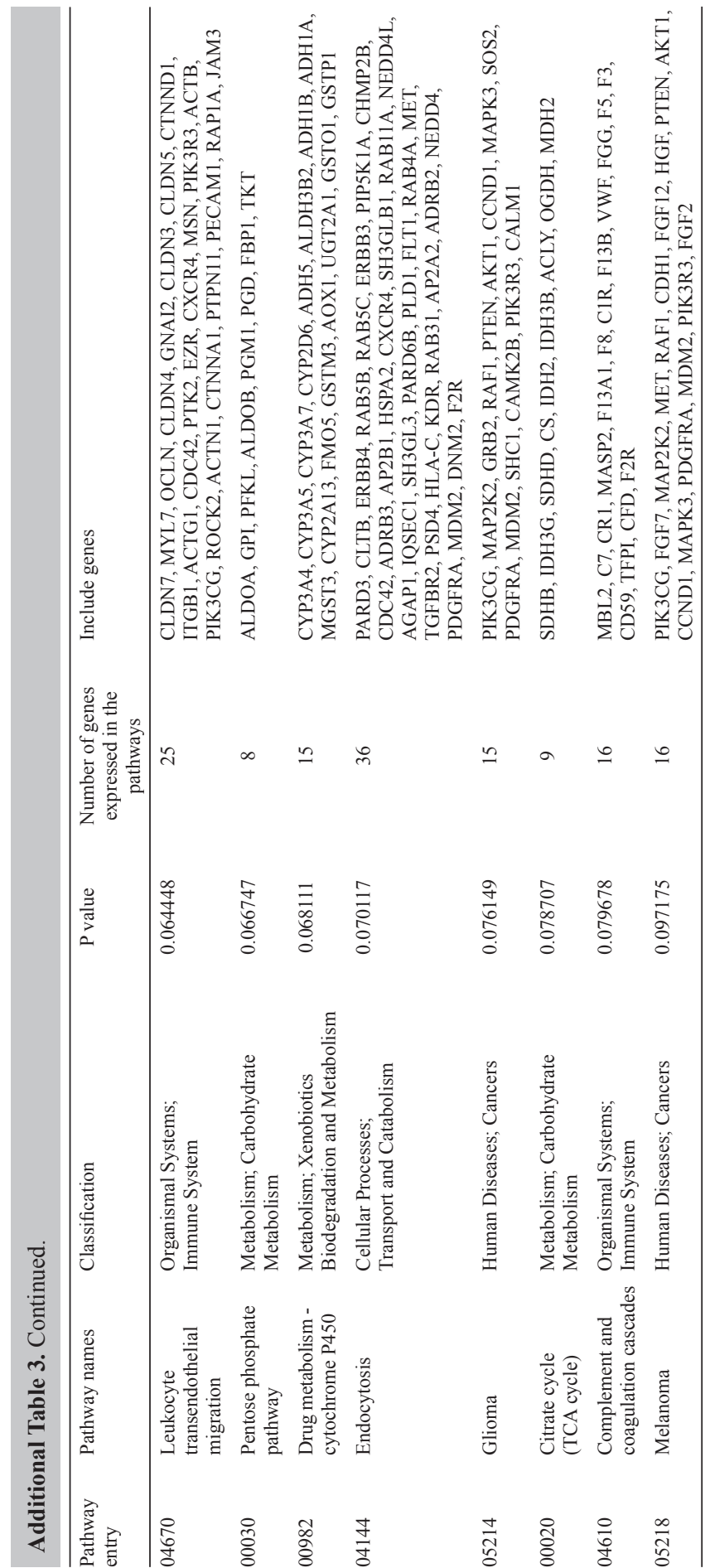


Additional Table 4. Common significant pathways obtained from 3 prostate cancer cell datasets by meta-analysis.

\begin{tabular}{|c|c|c|c|c|c|}
\hline $\begin{array}{l}\text { Pathway } \\
\text { entry }\end{array}$ & Pathway names & Classification & $P$ value & $\begin{array}{l}\text { Number of genes } \\
\text { expressed in the } \\
\text { pathways }\end{array}$ & Included genes \\
\hline 00330 & $\begin{array}{l}\text { Arginine and proline } \\
\text { metabolism }\end{array}$ & $\begin{array}{l}\text { Amino Acid } \\
\text { Metabolism }\end{array}$ & 0.002131 & 7 & $\begin{array}{l}\text { ODC1, PYCR1, GOT1, P4HA2, GLUD2, } \\
\text { GLUD1, GAMT }\end{array}$ \\
\hline 00900 & $\begin{array}{l}\text { Terpenoid backbone } \\
\text { biosynthesis }\end{array}$ & $\begin{array}{l}\text { Amino Acid } \\
\text { Metabolism }\end{array}$ & 0.005931 & 4 & FDPS, PMVK, ACAT2, ACAT1 \\
\hline 00100 & Steroid biosynthesis & Cancers & 0.00854 & 4 & TM7SF2, DHCR24, FDFT1, SC4MOL \\
\hline 00071 & Fatty acid metabolism & $\begin{array}{l}\text { Cell Growth and } \\
\text { Death }\end{array}$ & 0.018304 & 5 & $\begin{array}{l}\text { ACADVL, ACAA2, LOC648603, ACAT2, } \\
\text { ACAT1, DCI }\end{array}$ \\
\hline 00072 & $\begin{array}{l}\text { Synthesis and } \\
\text { degradation of ketone } \\
\text { bodies }\end{array}$ & Lipid Metabolism & 0.020758 & 3 & BDH2, ACAT2, ACAT1 \\
\hline 00250 & $\begin{array}{l}\text { Alanine, aspartate and } \\
\text { glutamate metabolism }\end{array}$ & Lipid Metabolism & 0.043597 & 4 & GOT1, GLUD2, GLUD1, ASNS \\
\hline 05200 & Pathways in cancer & Lipid Metabolism & 0.074605 & 14 & $\begin{array}{l}\text { CKS1B, MET, SMAD3, ITGA3, FZD4, } \\
\text { STAT3, FOS, CDKN1A, LAMA3, SLC2A1, } \\
\text { KX3-1, FAS, WNT7A, MYC }\end{array}$ \\
\hline 04115 & p53 signaling pathway & $\begin{array}{l}\text { Metabolism of Other } \\
\text { Amino Acids }\end{array}$ & 0.095163 & 5 & $\begin{array}{l}\text { CDKN1A, TP53I3, SERPINB5, FAS, } \\
\text { ADD45A }\end{array}$ \\
\hline 00471 & $\begin{array}{l}\text { D-Glutamine and } \\
\text { D-glutamate } \\
\text { metabolism }\end{array}$ & $\begin{array}{l}\text { Metabolism of } \\
\text { Terpenoids and } \\
\text { Polyketides }\end{array}$ & 0.098434 & 2 & GLUD2, GLUD1 \\
\hline
\end{tabular}


Additional Table 5. Common crossing significant pathways between the results of GSEA and meta-analysis about prostate cancer tissues.

\begin{tabular}{|c|c|c|c|c|}
\hline $\begin{array}{l}\text { Pathway } \\
\text { entry }\end{array}$ & Pathway names & Classification & $\begin{array}{l}\text { er of genes } \\
\text { ssed in the } \\
\text { thways }\end{array}$ & Included genes \\
\hline 00010 & $\begin{array}{l}\text { Glycolysis/ } \\
\text { Gluconeogenesis }\end{array}$ & $\begin{array}{l}\text { Metabolism; } \\
\text { Lipid Metabolism }\end{array}$ & 6 & $\begin{array}{l}\text { ADH1A, ADH1B, ADH5, ALDH1B1, } \\
\text { ALDH3B2, PGK1 }\end{array}$ \\
\hline 00050 & $\begin{array}{l}\text { Starch and sucrose } \\
\text { metabolism }\end{array}$ & $\begin{array}{l}\text { Metabolism; Amino } \\
\text { Acid Metabolism }\end{array}$ & 5 & GAA, PYGL, PYGM, UGDH, UGP2 \\
\hline 00982 & Drug metabolism & $\begin{array}{l}\text { Metabolism; Xenobiotics } \\
\text { Biodegradation and } \\
\text { Metabolism }\end{array}$ & 11 & $\begin{array}{l}\text { ADH1A, ADH1B, ADH5, ALDH3B2, AOX1, } \\
\text { CYP3A4, CYP3A5, FMO5, GSTM3, GSTO1, } \\
\text { GSTP1 }\end{array}$ \\
\hline 04010 & $\begin{array}{l}\text { MAPK signaling } \\
\text { pathway }\end{array}$ & $\begin{array}{l}\text { Environmental Information } \\
\text { Processing; Signal } \\
\text { Transduction }\end{array}$ & 17 & $\begin{array}{l}\text { CD14, CHUK, DUSP1, DUSP3, FLNA, FLNC, } \\
\text { FOS, GRB2, JUND, MEF2C, MYC, NF1, NFKB2, } \\
\text { NR4A1, PPP3CC, RRAS2, TGFB3 }\end{array}$ \\
\hline 04510 & Focal adhesion & $\begin{array}{l}\text { Environmental Information } \\
\text { Processing; Signal } \\
\text { Transduction }\end{array}$ & 28 & $\begin{array}{l}\text { BCL2, CAV2, CCND1, CCND2, COL6A1, COL6A2, } \\
\text { FLNA, FLNC, FLT1, GRB2, ILK, ITGA5, ITGA7, } \\
\text { ITGB3, ITGB4, KDR, LAMA5, MET, MYLK, PAK4, } \\
\text { PIK3R3, ROCK2, SHC1, SOS2, TLN1, TNC, TNXA, ZYX }\end{array}$ \\
\hline 04512 & $\begin{array}{l}\text { ECM-receptor } \\
\text { interaction }\end{array}$ & $\begin{array}{l}\text { Environmental Information } \\
\text { Processing; Signaling } \\
\text { Molecules and Interaction }\end{array}$ & 12 & $\begin{array}{l}\text { AGRN, CD44, COL6A1, COL6A2, ITGA5, ITGA7, } \\
\text { ITGB3, ITGB4, LAMA4, LAMA5, SDC2, TNC }\end{array}$ \\
\hline 04530 & Tight junction & $\begin{array}{l}\text { Environmental Information } \\
\text { Processing; Signaling Molecules } \\
\text { and Interaction }\end{array}$ & 9 & $\begin{array}{l}\text { CASK, CLDN3, CLDN4, CLDN5, INADL, MYH9, } \\
\text { RKCD, RRAS2, SYMPK }\end{array}$ \\
\hline 04540 & Gap junction & Cellular Processes; Cell Motility & 8 & $\begin{array}{l}\text { CSNK1D, GJA1, GRB2, ITPR1, ITPR2, ITPR3, } \\
\text { TUBA4A, TUBB2C }\end{array}$ \\
\hline 04810 & $\begin{array}{l}\text { Regulation of } \\
\text { actin cytoskeleton }\end{array}$ & Cellular Processes; Cell Motility & 15 & $\begin{array}{l}\text { BAIAP2, CD14, EZR, IQGAP1, IQGAP2, ITGA5, } \\
\text { ITGA7, ITGB3, ITGB4, MYH9, MYLK, PAK4, } \\
\text { PIK3R3, ROCK2, RRAS2 }\end{array}$ \\
\hline 04910 & $\begin{array}{l}\text { Insulin signaling } \\
\text { pathway }\end{array}$ & $\begin{array}{l}\text { Organismal Systems; } \\
\text { Endocrine System }\end{array}$ & 11 & $\begin{array}{l}\text { CALM1, FASN, GRB2, IRS1, PDE3B, PIK3R3, } \\
\text { PRKAA1, PYGL, PYGM, SHC1, TSC2 }\end{array}$ \\
\hline 05200 & Pathways in cancer & Human Diseases; Cancers & 19 & $\begin{array}{l}\text { ABL1, BCL2, CCND1, CDH1, CHUK, CTBP2, } \\
\text { DAPK1, FOS, GRB2, GSTP1, JUP, KLK3, LAMA4, } \\
\text { LAMA5, MYC, NFKB2, PIK3R3, TGFB3, TRAF4 }\end{array}$ \\
\hline 05211 & $\begin{array}{l}\text { Renal cell } \\
\text { carcinoma }\end{array}$ & Human Diseases; Cancers & 5 & GRB2, PAK4, PIK3R3, PTPN11, TGFB3 \\
\hline 05214 & Glioma & Human Diseases; Cancers & 5 & CALM1, CCND1, GRB2, PIK3R3, SHC1 \\
\hline 05220 & $\begin{array}{l}\text { Chronic myeloid } \\
\text { leukemia }\end{array}$ & Human Diseases; Cancers & 11 & $\begin{array}{l}\text { ABL1, CCND1, CHUK, CTBP2, GRB2, MYC, } \\
\text { PIK3R3, PTPN11, SHC1, SMAD3, TGFB3 }\end{array}$ \\
\hline 05221 & $\begin{array}{l}\text { Acute myeloid } \\
\text { leukemia }\end{array}$ & Human Diseases; Cancers & 6 & CCND1, CHUK, GRB2, JUP, MYC, PIK3R3 \\
\hline 05222 & $\begin{array}{l}\text { Small cell lung } \\
\text { cancer }\end{array}$ & Human Diseases; Cancers & 9 & $\begin{array}{l}\text { BCL2, CCND1, CHUK, FHIT, LAMA4, LAMA5, } \\
\text { MYC, PIK3R3, TRAF4 }\end{array}$ \\
\hline
\end{tabular}


Q.Y. Ning et al.

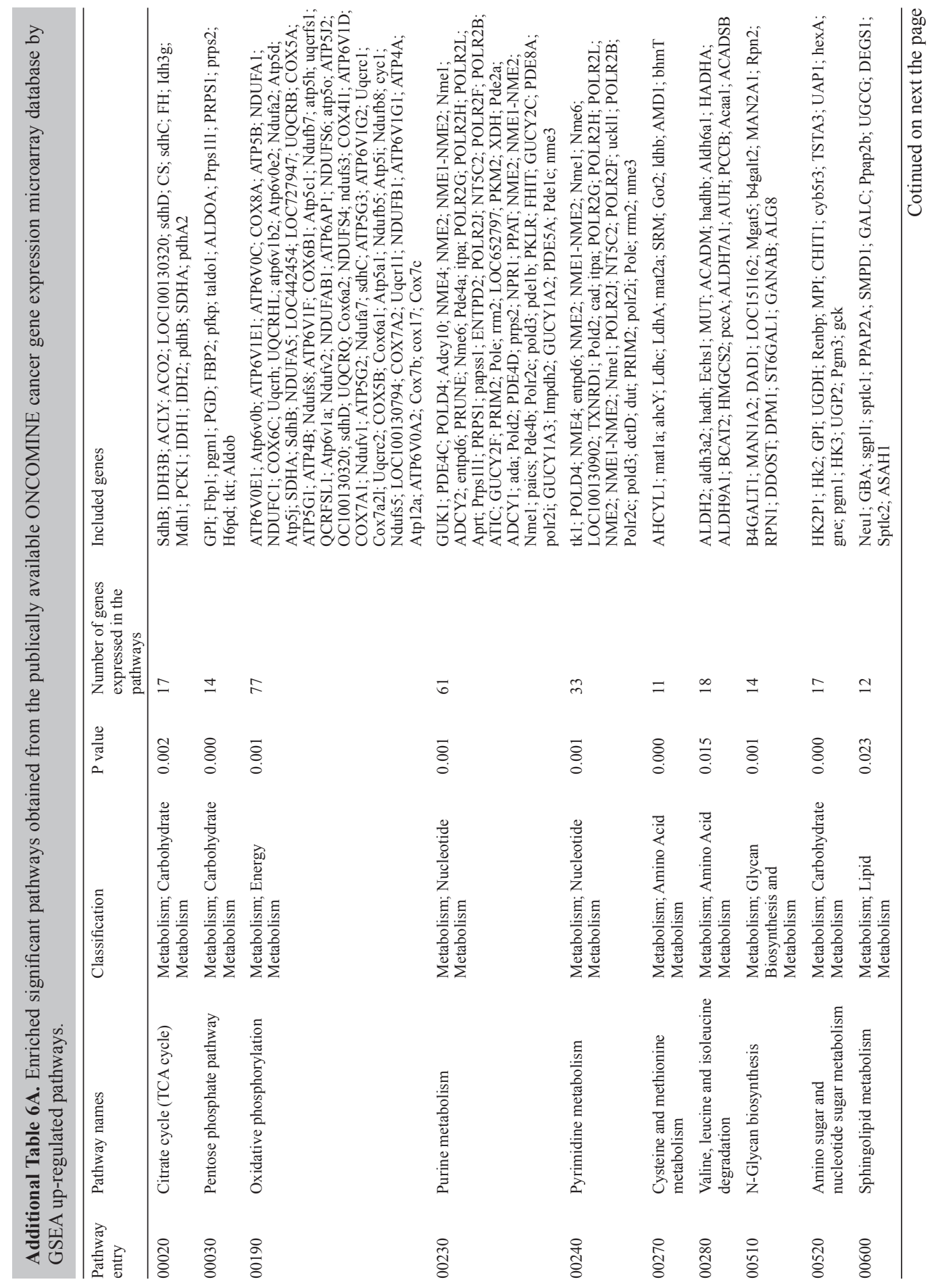

Genetics and Molecular Research 10 (4): 3856-3887 (2011) 


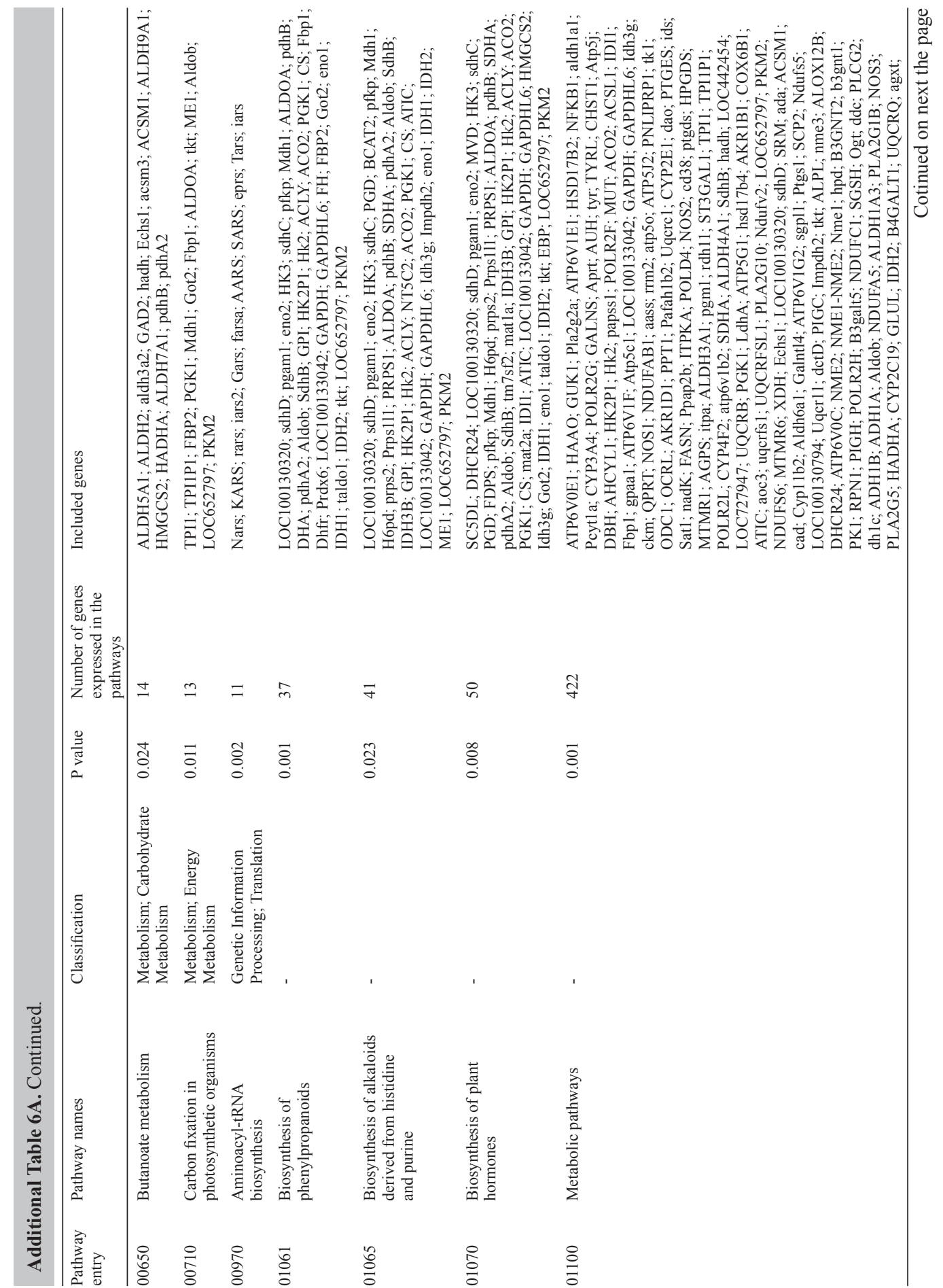




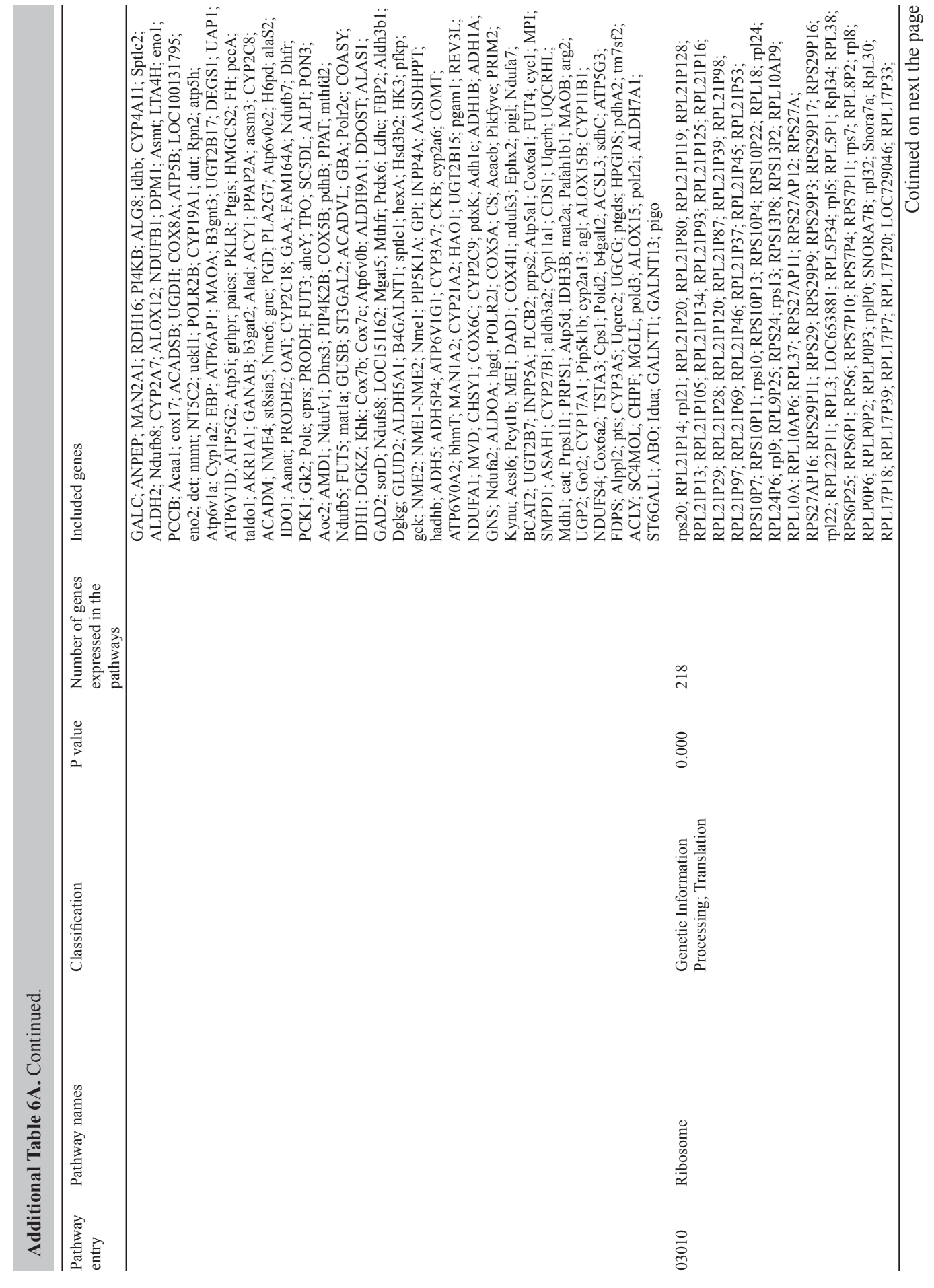



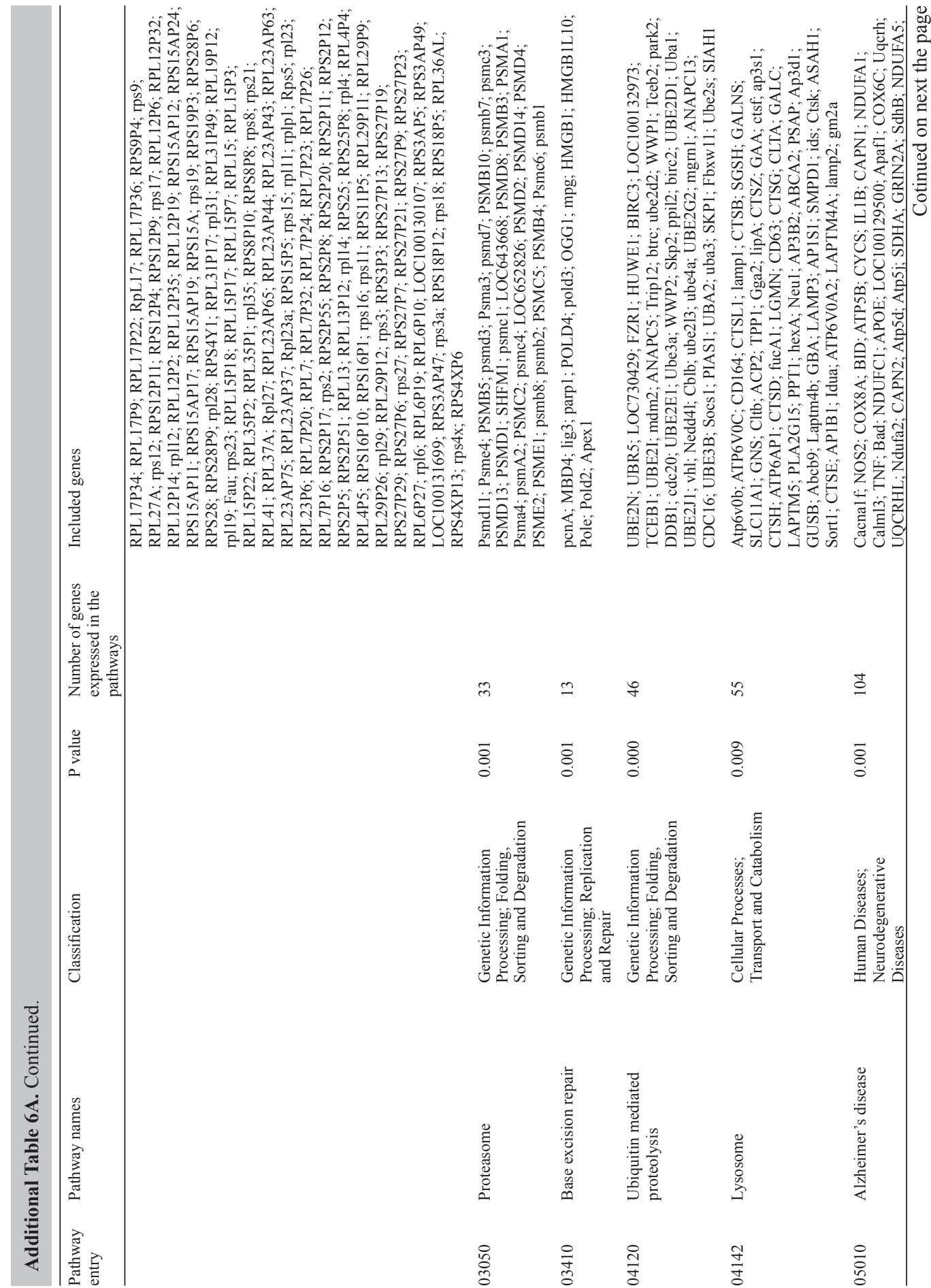

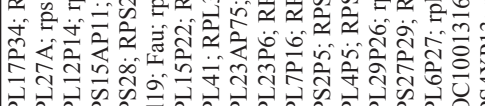

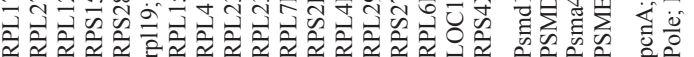

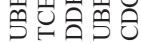

tocts
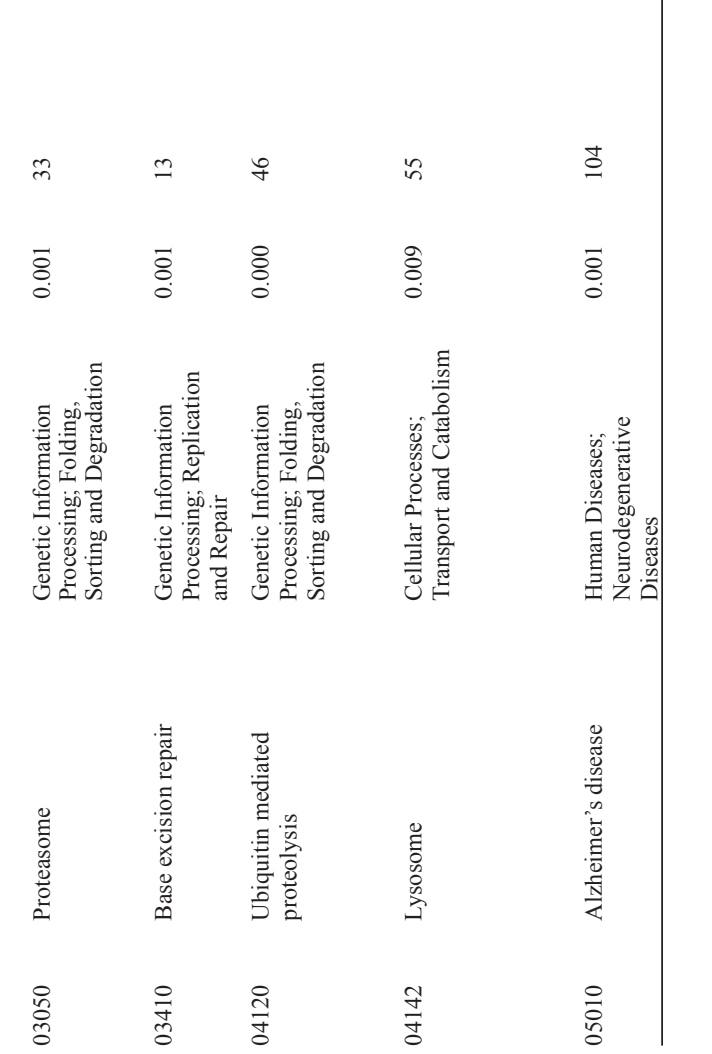

Genetics and Molecular Research 10 (4): 3856-3887 (2011) 


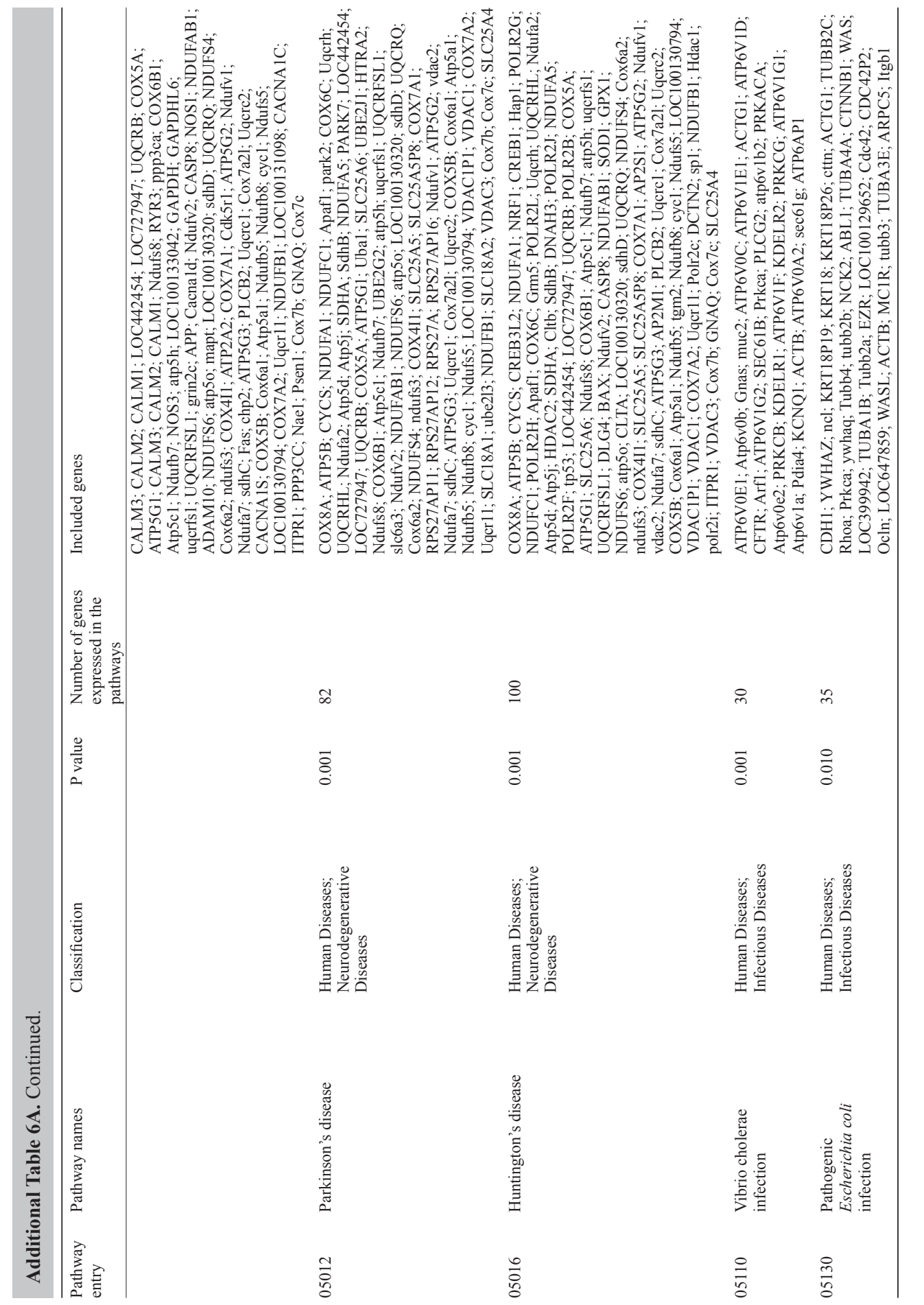

Genetics and Molecular Research 10 (4): 3856-3887 (2011) 


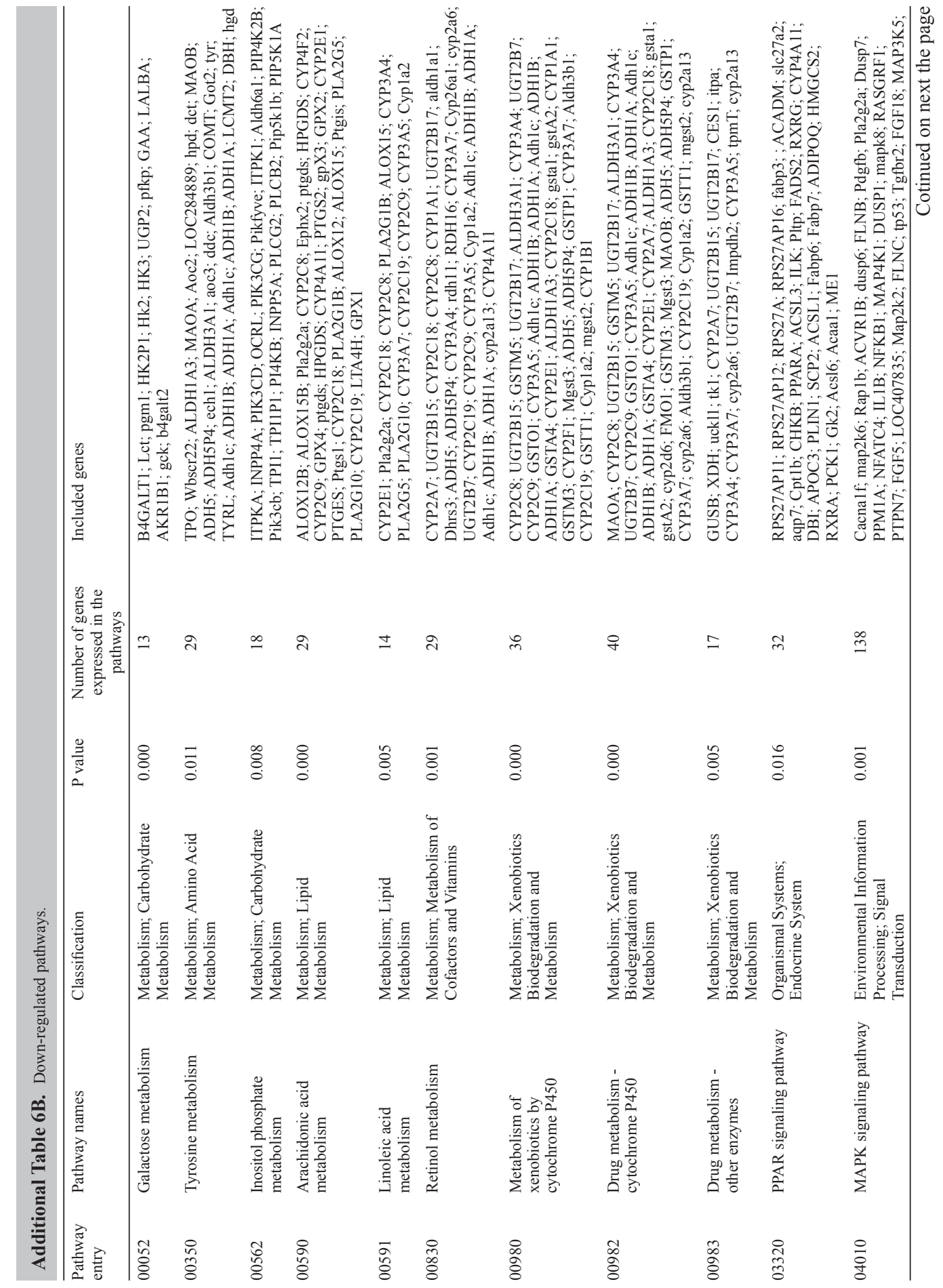


Q.Y. Ning et al.

3878

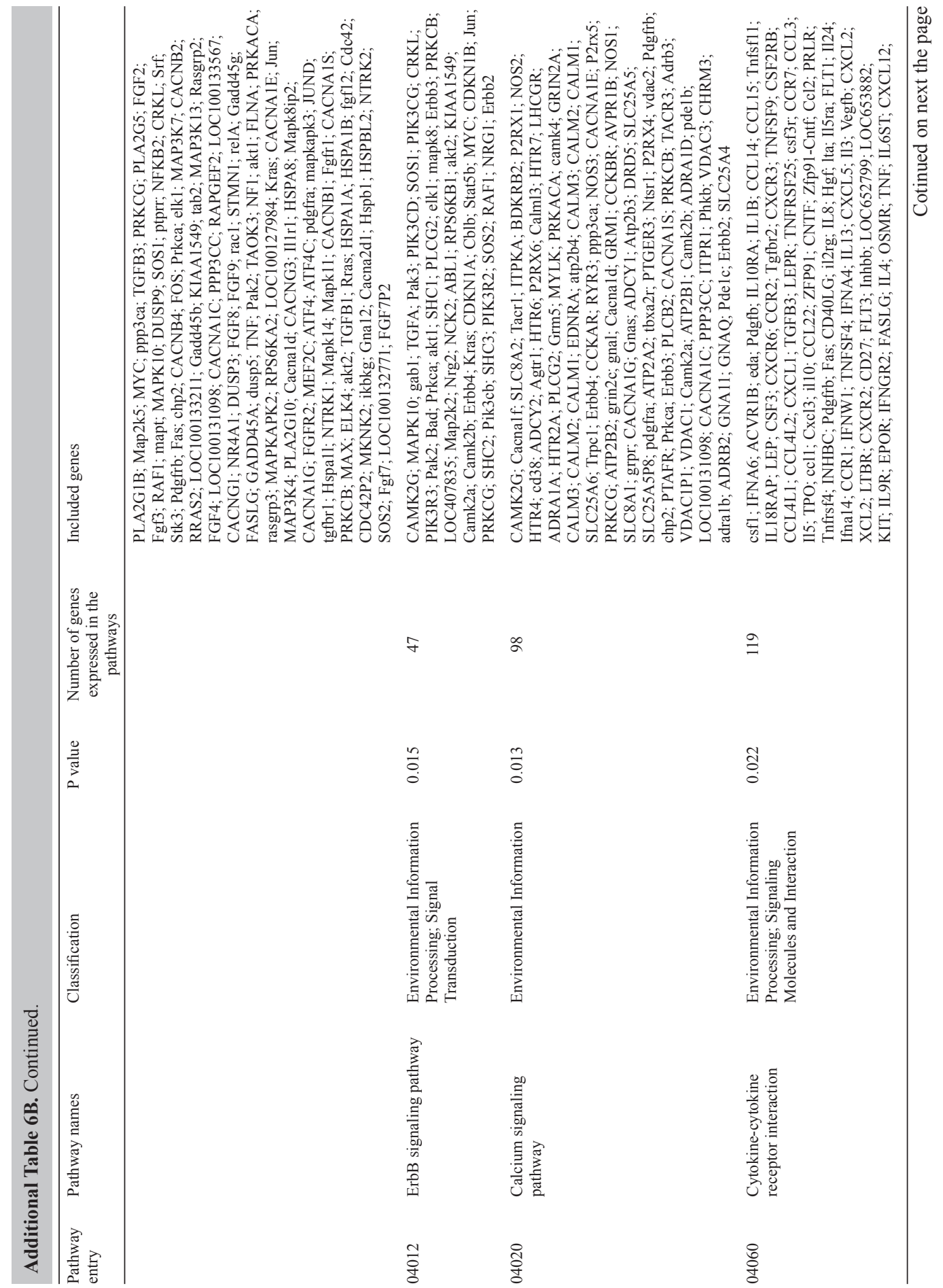

Genetics and Molecular Research 10 (4): 3856-3887 (2011) 
Key pathways involved in prostate cancer

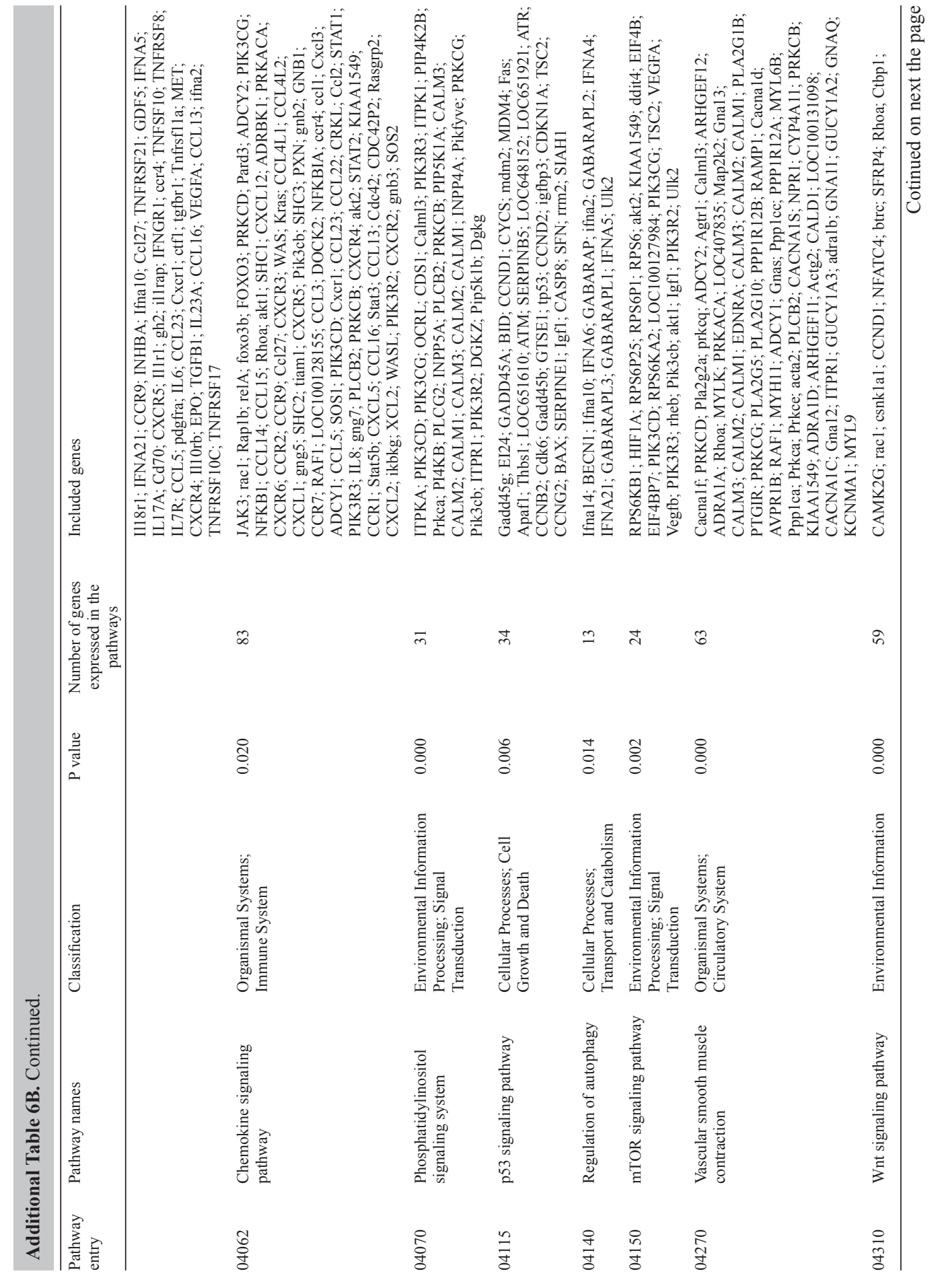

Genetics and Molecular Research 10 (4): 3856-3887 (2011) 
Q.Y. Ning et al.

3880

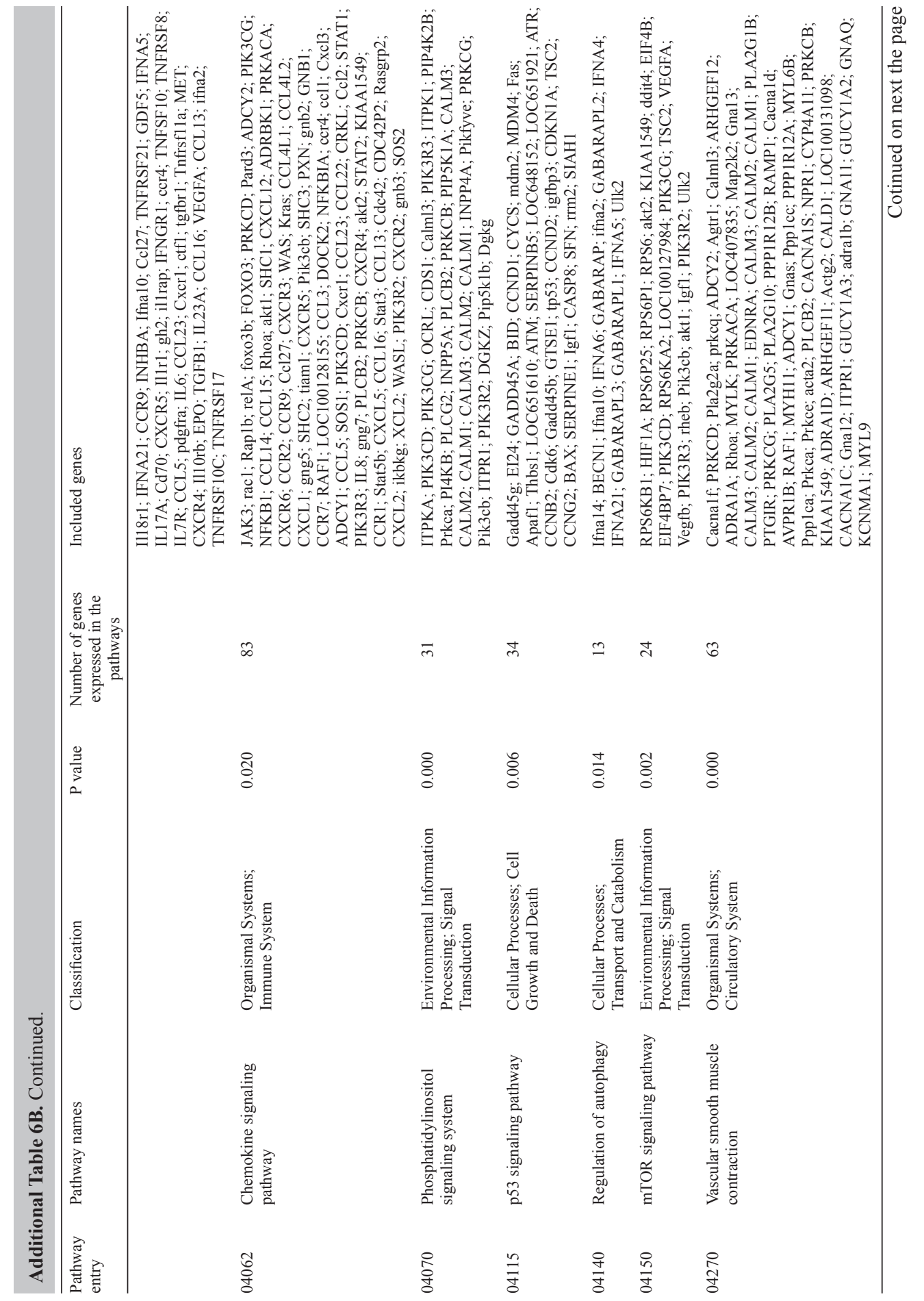

Genetics and Molecular Research 10 (4): 3856-3887 (2011) 

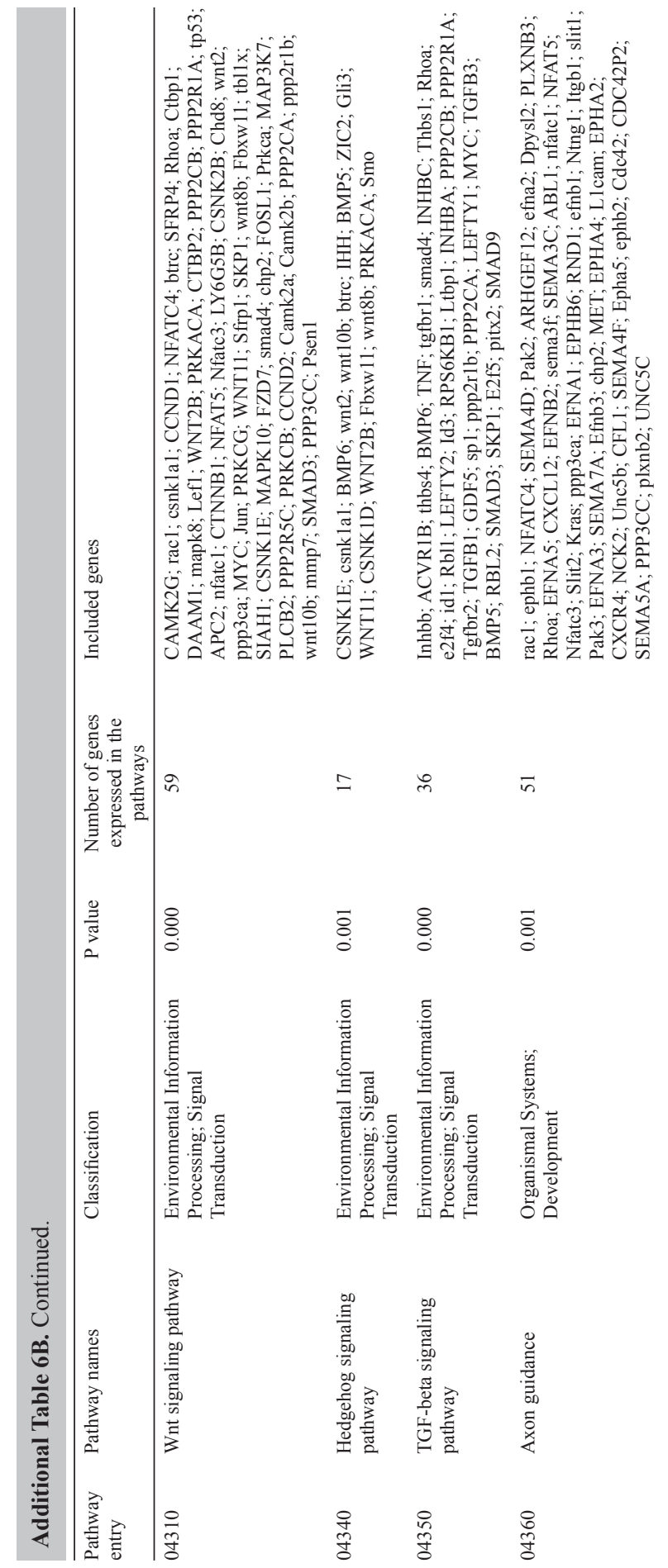

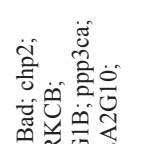

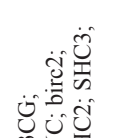

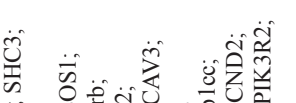

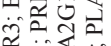

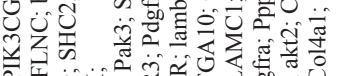

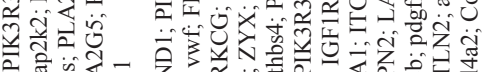

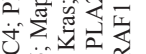

会势

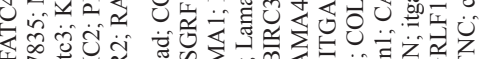

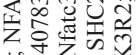

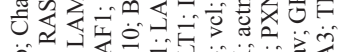

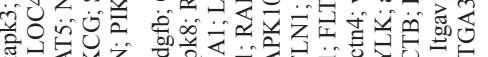

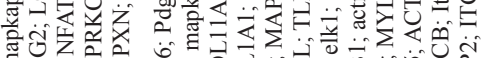

ह 0 i

ن्ల

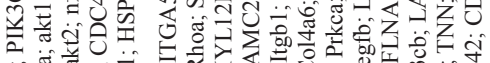

仓ि讠

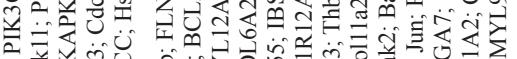

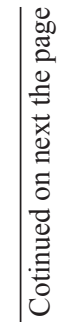

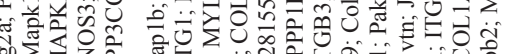

कू

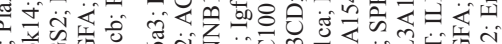

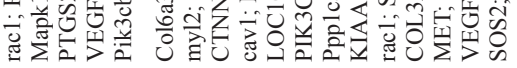

$=$

$\infty \quad \bar{n}$

$\exists \quad \stackrel{\Xi}{\exists}$

$\stackrel{5}{\circ}$

$\stackrel{0}{\circ} \stackrel{0}{0}$
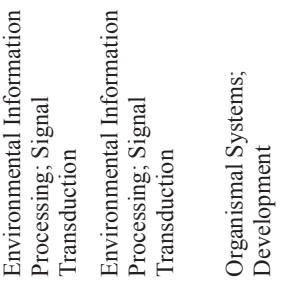

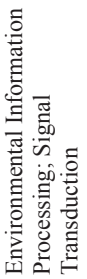

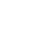

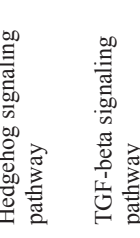

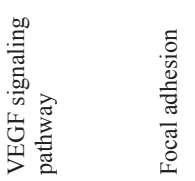

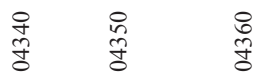

$\underset{\substack{9 \\ \text { s }}}{2}$

잉

Genetics and Molecular Research 10 (4): 3856-3887 (2011) 
Q.Y. Ning et al.

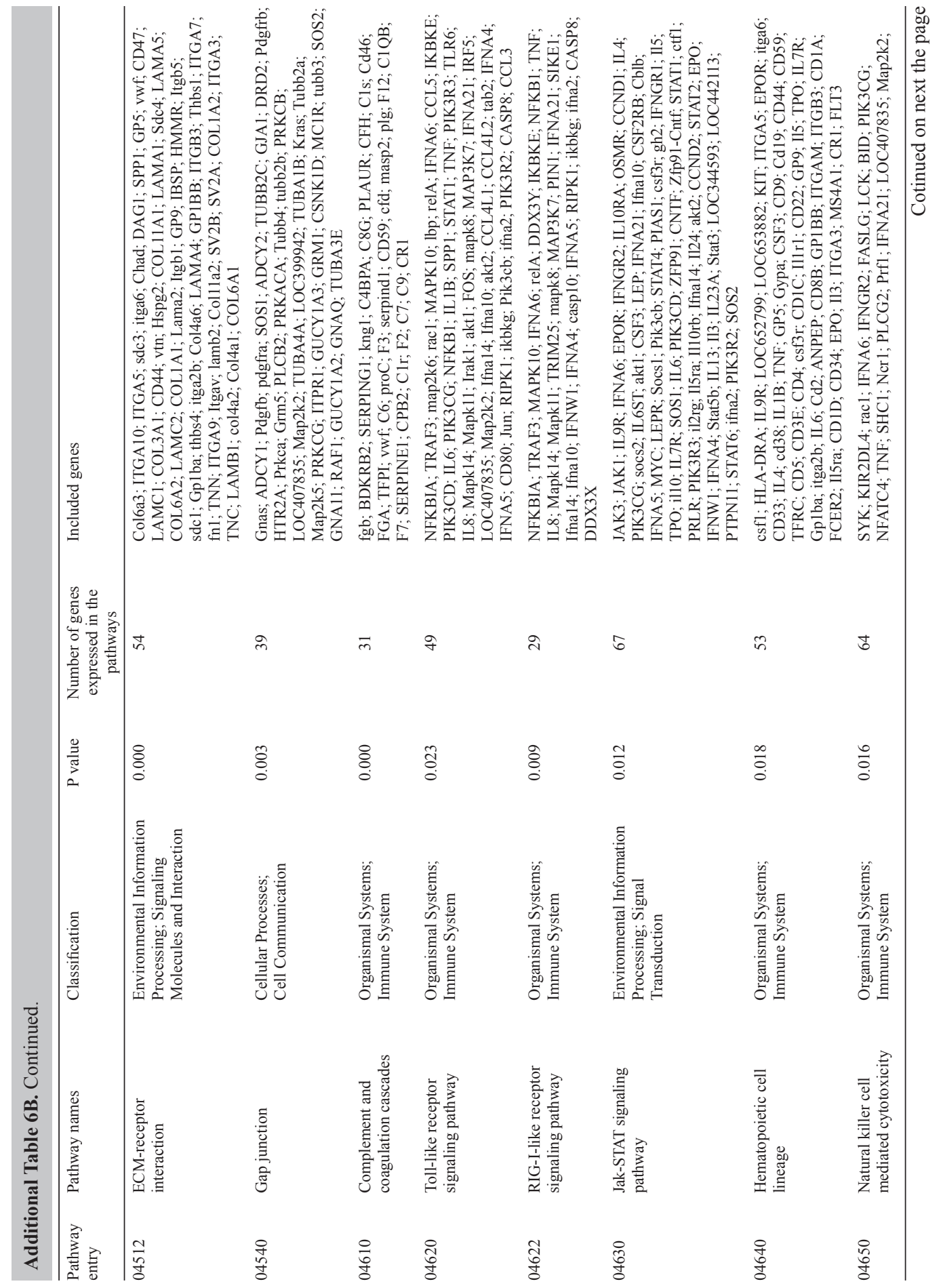

Genetics and Molecular Research 10 (4): 3856-3887 (2011) 
$\stackrel{\circ}{n}$

$\stackrel{\text { Iิ }}{\circ}$

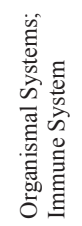

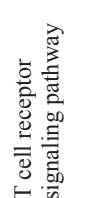

0
0
0
0
٪

$\stackrel{\square}{\circ} \quad$

$\stackrel{\circ}{\circ}$

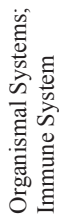

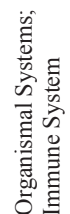

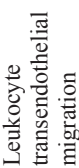

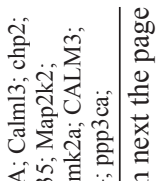

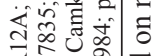

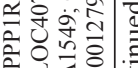

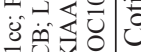

究

苍它号

«过

安远荡

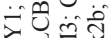

记

丕 قैं $\ddot{z} \ddot{z}$

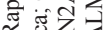
is if

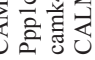


Q.Y. Ning et al.

3884

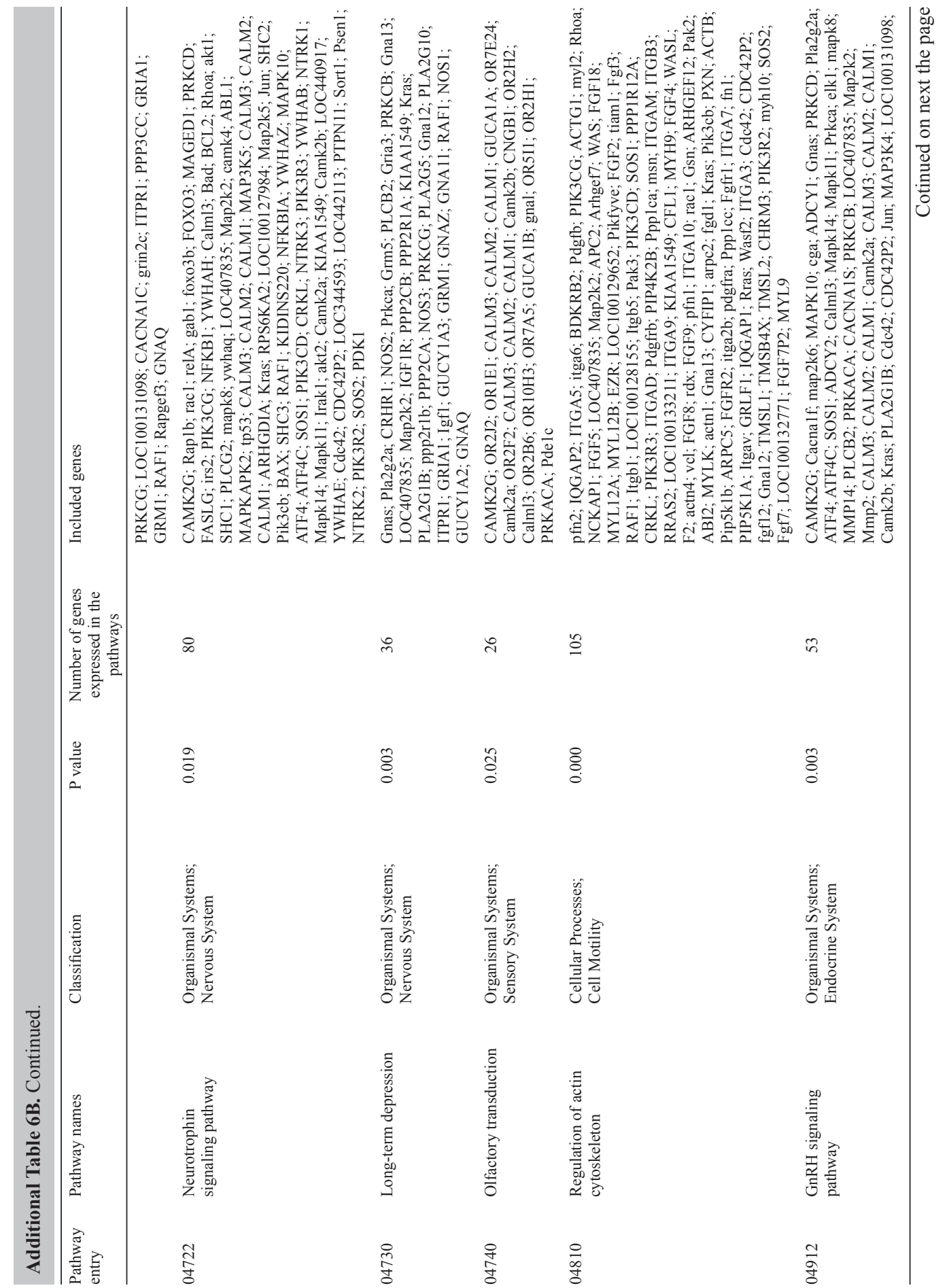

Genetics and Molecular Research 10 (4): 3856-3887 (2011) 
Key pathways involved in prostate cancer

3885

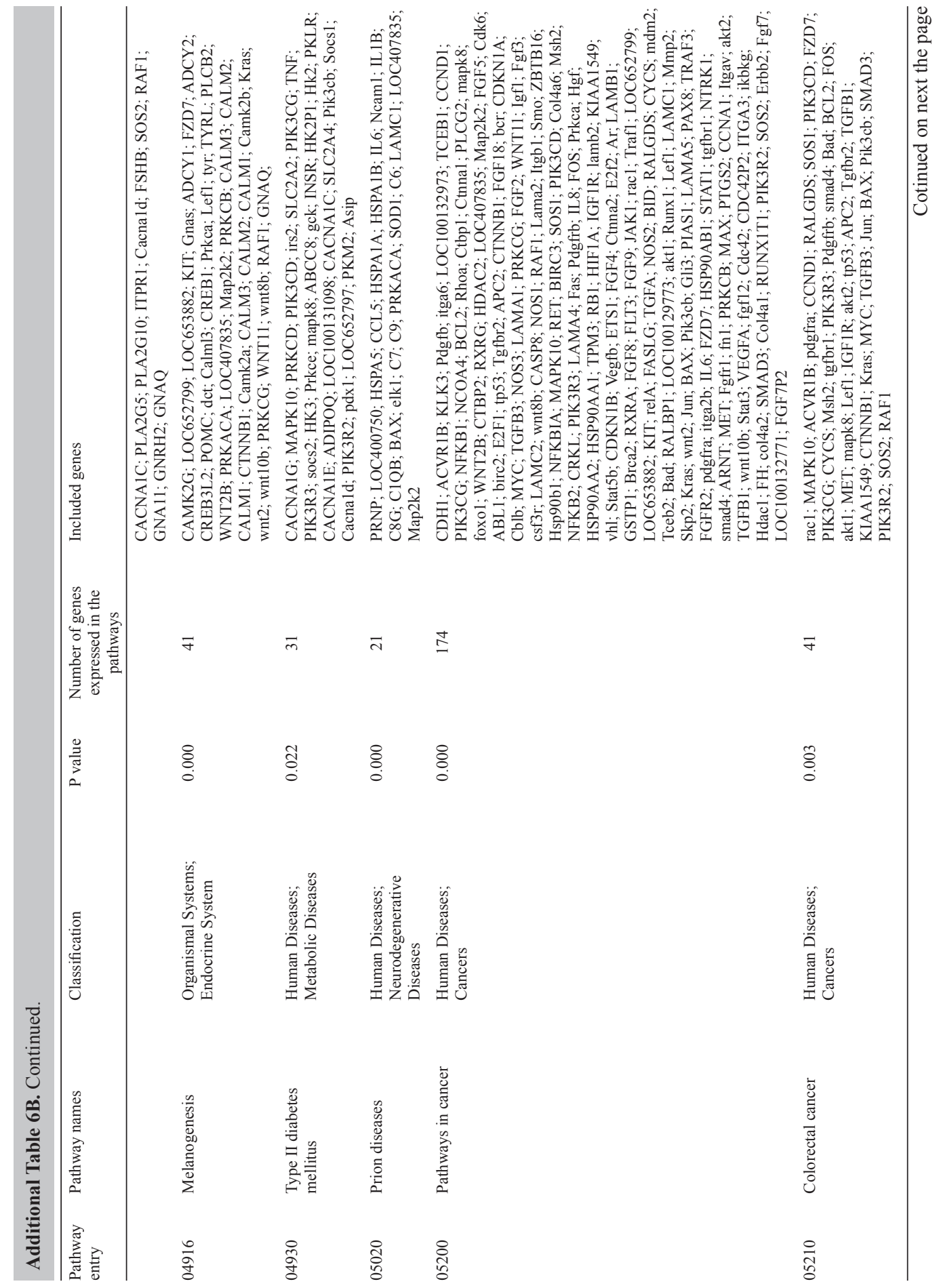

Genetics and Molecular Research 10 (4): 3856-3887 (2011)

CFUNPEC-RP www.funpecrp.com.br 
Q.Y. Ning et al.

3886

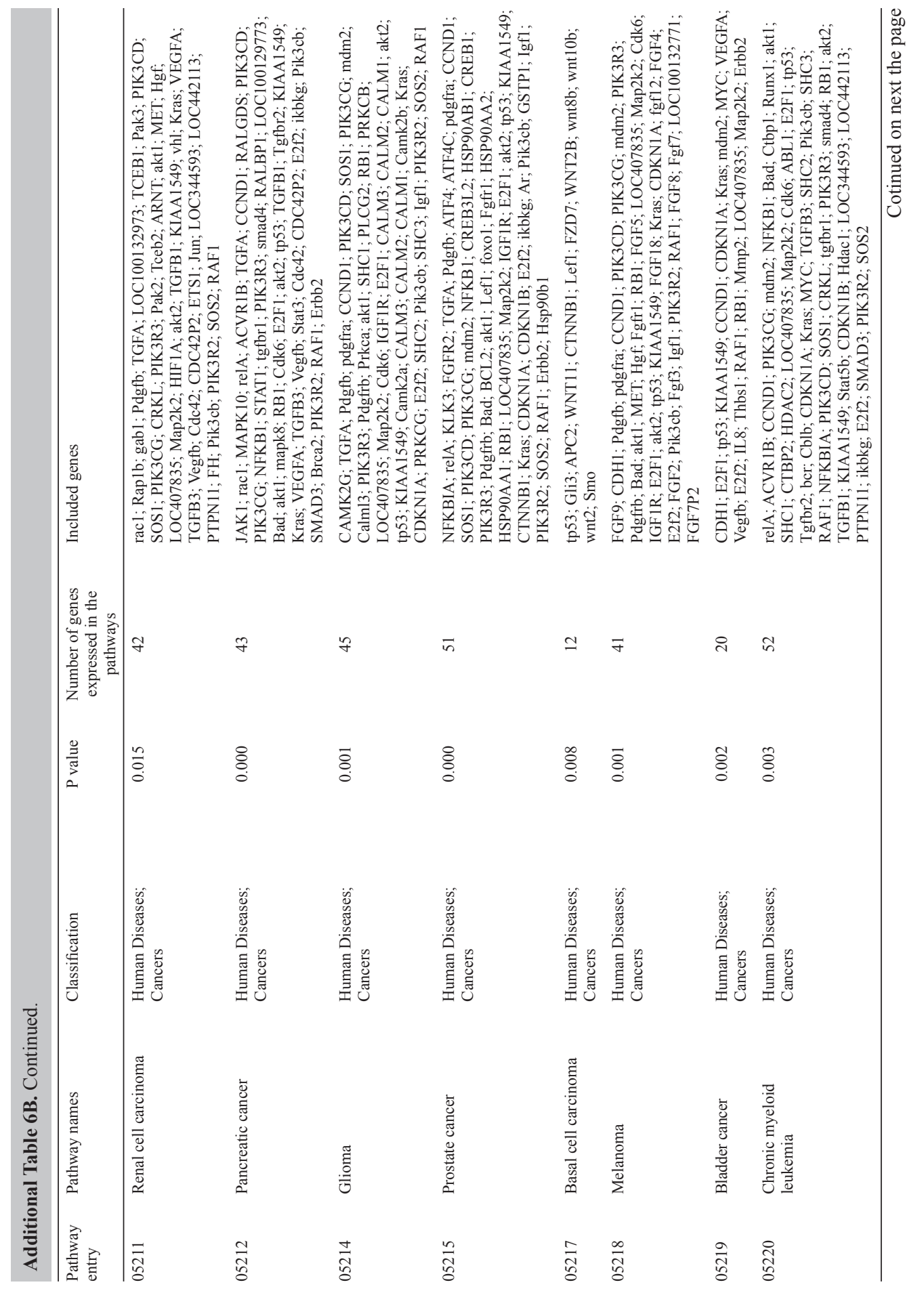

Genetics and Molecular Research 10 (4): 3856-3887 (2011) 


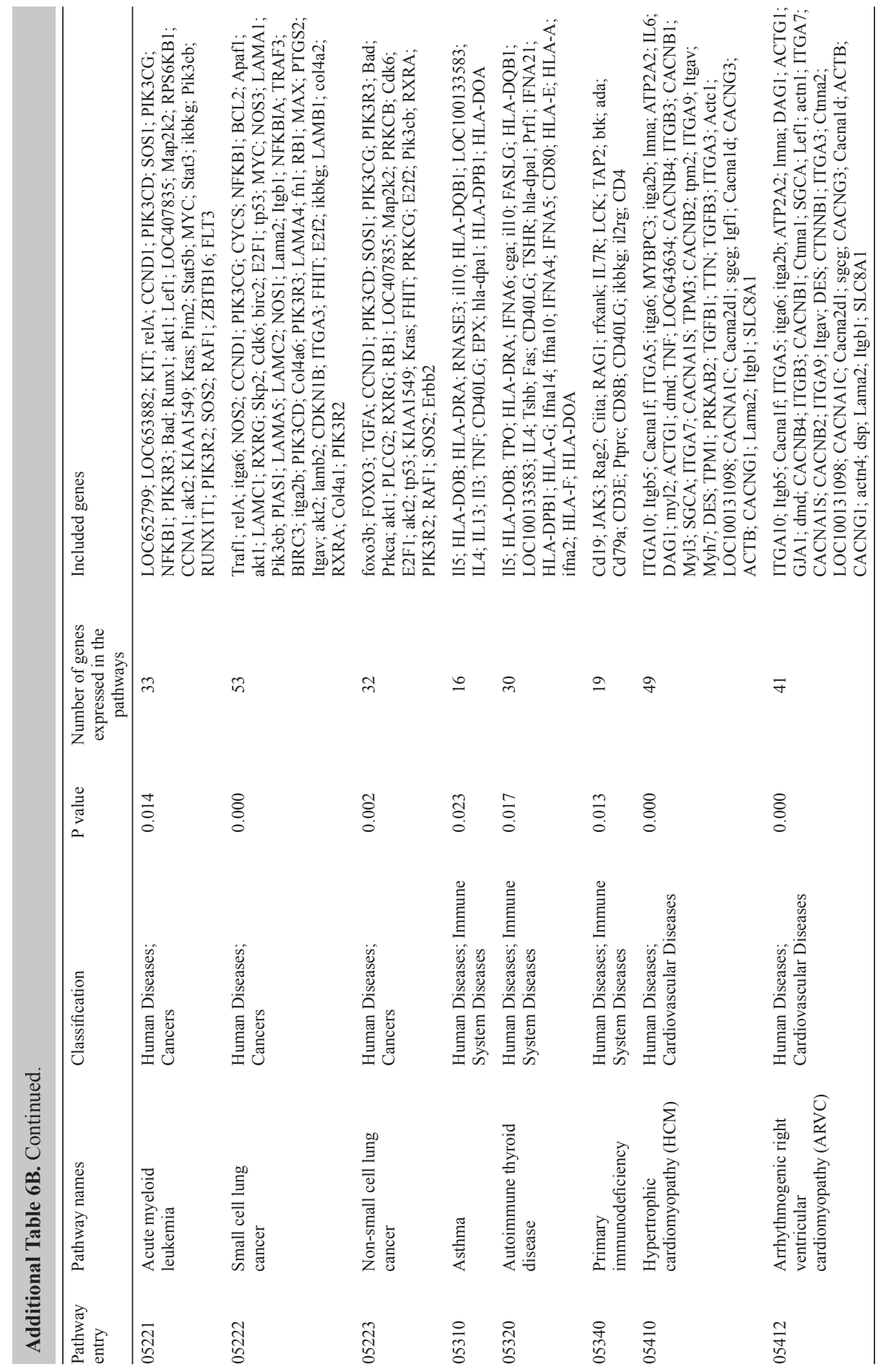

